\title{
Fatigue Crack Monitoring of T-Type Joints in Steel Offshore Oil and Gas Jacket Platform
}

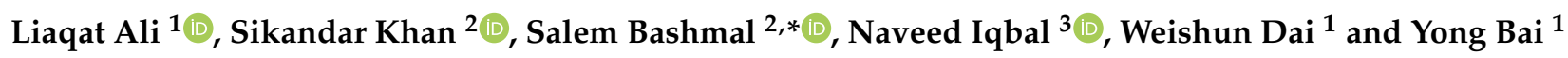 \\ 1 College of Civil Engineering \& Architecture, Zhejiang University, Hangzhou 310058, China; \\ drali169@zju.edu.cn (L.A.); weishundai@zju.edu.cn (W.D.); baiyong@zju.edu.cn (Y.B.) \\ 2 Department of Mechanical Engineering, King Fahd University of Petroleum and Minerals, \\ Dhahran 31261, Saudi Arabia; sikandarkhan@kfupm.edu.sa \\ 3 Department of Electrical Engineering, King Fahd University of Petroleum and Minerals, \\ Dhahran 31261, Saudi Arabia; naveediqbal@kfupm.edu.sa \\ * Correspondence: bashmal@kfupm.edu.sa
}

Citation: Ali, L.; Khan, S.; Bashmal, S.; Iqbal, N.; Dai, W.; Bai, Y. Fatigue Crack Monitoring of T-Type Joints in Steel Offshore Oil and Gas Jacket Platform. Sensors 2021, 21, 3294. https://doi.org/10.3390/s21093294

Academic Editor: Andrzej Katunin

Received: 15 February 2021

Accepted: 1 May 2021

Published: 10 May 2021

Publisher's Note: MDPI stays neutral with regard to jurisdictional claims in published maps and institutional affiliations.

Copyright: () 2021 by the authors. Licensee MDPI, Basel, Switzerland. This article is an open access article distributed under the terms and conditions of the Creative Commons Attribution (CC BY) license (https:// creativecommons.org/licenses/by/ $4.0 /)$.

\begin{abstract}
Several approaches have been used in the past to predict fatigue crack growth rates in T-joints of the offshore structures, but there are relatively few cases of applying structural health monitoring during the non-destructive testing of jacket platforms. This paper presents an experimental method based on the sensing of the piezoelectric sensors and finite element analysis method for studying the fatigue cracks in the offshore steel jacket structure. Three types of joints are selected in the current research work: T-type plate, T-type tube-plate, and T-type tube joints. The finite element analysis model established in the current study computes and analyzes the high stress and high strain regions in the T-type joints. The fatigue damage in the T-type joints was successfully detected by utilizing both the finite element analysis and experimental methods. The results showed that fatigue cracks of the three types of joints are prone to appear at the weld toe and spread in the welding direction. The fatigue damage location of T-type plate and T-type tube-plate joints is more concentrated in the upper weld toe area, and the fatigue damage location of the T-type tube joint is closer to the lower weld toe area.
\end{abstract}

Keywords: fatigue crack; damage detection; welded metallic joints; finite element method; structural health monitoring; piezoelectric sensors

\section{Introduction}

In the last few decades, a number of jacket structures were built to mine subsea resources and many of them have already been operated for over 20 years. Therefore, technical assessments, such as environmental condition analysis and corrosion or fatigue analysis, are needed to continuously check the condition of these jacket structures. Structural reliability of the offshore structures has been discussed in the literature by Madsen et al. [1], Moan [2], and Melcher [3]. Offshore pipelines are used to carry oil and gas from wellhead to manufacture services. In 2016, more than 2000 metric tons of oil and gas leaked from these offshore facilities. The most common failure mode in offshore structures is the one caused by the fatigue [4,5]. The structure may also fail when the load is more than the yield strength [6]. The steel jackets structure has been extensively used in the offshore oil and gas facilities for the past two decades [7] in (Bohai Bay) China, Gulf of Mexico, and Brazil. When the structure reaches the design service, the jacket plays a most important role in structural aging when exposed to environmental circumstances such as waves currents and wind loads. The final strength deteriorates with the progress of cracks as well as corrosion, producing the risk of collapse or failure of the entire jacket and causes losses of life, property and possibly causes environmental contamination. Few features of aged jacket fatigue life re-evaluation are given in [8], where the failure evaluation was achieved 
by the pushover technique. The key purpose for this re-evaluation might be the need to extend safety and life expectancy.

Studies on the worldwide nonlinear collapse analysis of three-dimensional steel jackets have also been performed in the literature [9]. The strength of the tubular structure as a ring-cured DT fitting in offshore jackets was analyzed using a finite element technique by Lee and Parry [10]. Reliability fatigue analysis was performed on jacket support considering corrosion as well as inspection by Dong et al. [11]. The effects of corrosion and cracks on the ultimate strength of aging ships were studied by Paik and Thayamballi [12]. Reliability analysis of damaged ships was also conducted where the resistance of older ships was reduced to initial yielding, which would underestimate or miscalculate the final strength $[13,14]$. In the literature, the collapse of the ship's plate due to cracks, dents, and corrosion was evaluated by experimental and numerical approaches $[15,16]$. Based on experimental and numerical outcomes, an overall expression of the final strength of the plate with cracks was obtained by Paik and Kumar [17]. A recent experimental survey of tiny box beams with mild, average, and severe corrosion was conducted by Saad et al. $[18,19]$.

Various studies in the literature are focused on loading, operation, structural harm and on the decay of the fixed and floating offshore structures [20-22]. Because of the complication of the subject and all its parameters, it is impractical to collect an overall fatigue analysis of all relevant variables. As a result, some researchers have concentrated on the individual significance of a topic to global panoramas. Jimenez-Martinez [23], reviewed the statistical fatigue damage assessment of offshore fatigue under random loading. It was concluded that experimental evaluations must describe the scattering of structural and macro layers, including substances from environmental conditions and random reactions.

Velarde et al. [24-26] described the effects of the uncertainty of loading on inducing cumulative damage from fatigue. Zhu et al. [27] investigated the accumulation of nonlinear damage based on the heterogeneous curve model. Farhan et al. [28] recommended a fatigue life for an onshore hybrid wind turbine, based on the multi-axis damage criteria. Sabakhty and Khansari [29], calculated the dynamic reaction of jacket structure under linear also nonlinear wave models to investigate the validity of linear wave models in different ocean states and also developed a finite element model to estimate the fatigue life. Meng et al. [30] puts forward a reliability-based optimization scheme based on saddle point approximation, which is suitable for offshore structures.

Zhang et al. [31] examined the effects of coupled wind loads on fixed tripod offshore wind turbines and floating fatigue assessments. Similarly, Fan et al. [32] evaluated cumulative fatigue damage of the offshore wind turbine structures with various wind loading conditions. Many other scientific studies in the literature have been performed related to the offshore jacket-type, fixed jacket platform, and offshore structural aspects [33-37], structural durability $[38,39]$, new design solutions [40], nonlinear effects of fatigue analysis [41], time domain analysis gap effect [42], effects of stress concentration factors on offshore tubular connections [43,44], and S-N curves [45-48].

Fatigue is one of the main failure forms in offshore steel jacket platforms. To assess fatigue damage, these platforms are regularly inspected over their life span. Fatigue damage inspection information mainly includes crack measurements [49]. Moreover, the fatigue reliability evaluation of welding joints is carried out using two different methods, the first is based on stress life curve, also called linear damage accumulation law, the second is based on the fatigue crack growth analysis, as well as failure standards $[49,50]$. The first method is used during the design phase, to evaluate the reliability of the existing or planned design structure solutions [51]. The first method cannot contain information about the size of the crack while the second method relies on linear elastic fracture dynamics and can be used to check the reliability of the structures [52-54].

The birth of intelligent materials for example piezoelectric (PZT) sensors that are based on the non-destructive testing approach, has revolutionized the field of structural health monitoring. Although a comparatively new non-destructive test technique called 
electromechanical (EMI) technology has been studied for more than 20 years, there are still various problems that need to be solved before it can be applied to actual structures [55]. The well-designed structural health monitoring system minimizes the overall maintenance costs of the structure, by detecting the damage at an early stage, resulting in early action to prevent further damage. Piezoelectric transducer can function both as a sensor as well as actuator [56].

High-strength low-alloy (HSLA) steel was initially developed in the 1960s for offshore pipeline. Pipes are normally made of high-strength low-alloy steel because it is stronger and tougher than mild carbon steel $[57,58]$. Furthermore, HSLA steel are used in engineering construction [59], automotive [60], as well as offshore structures [61]. The main advantages of HSLA steel are that it reduces the thickness and weight of components and also reduces the welding costs [62-65]. There are three key techniques of underwater welding, local dry cavity, wet welding and drying. The most commonly used form is the wet welding in which arcing and joints are in direct contact with water [66-70]. Wet welding can be done by using shielded electrodes, flux leather wires and also using few other welding procedures [71-75].

As a welding environment, water causes many problems in the quality of the acquired joints. The most common problem in underwater welding is the cold cracking [76,77]. High cooling rates in wet welding results in emulsified structures. Welding joint structures have the characteristics of high hardness and low plasticity. Cold cracks are also called hydrogen cracks and it account for more than 90 percent of the actual steel structure welds cracks [78]. Cold welding usually occurs shortly after welding, generally within 48 hours. Due to high temperatures, water is converted into hydrogen $\left(\mathrm{H}_{2}\right)$ gas in an arc. Hydrogen cracks are usually very fine and are hard to detect [79].

Practically, pre-heating is the extremely valuable way to avoid cold cracking [79]. The cold cracking behaviour is controlled by the thickness of the plate, the hydrogen content of the welding metal, the heat input during the welding process, the residual stress state of the welding area and also by the chemical composition of the metal $[78,79]$. It is vital to notice the relationship between welded metal microstructures and welding conditions. To this end, the scientific researchers pays attention to the susceptibility of steel to cold cracking by controlling welding parameters, preheating, applying low hydrological consumables and welding processes [80].

The form drilling and form tapping techniques can be used for the rapid and economical production of nutless bolted joins. Using these techniques, threaded holes can easily be produced on couples of dissimilar metal alloys, as it is the case of steels and aluminium alloys. During this technique a fastener can be introduced and screwed for achieving a tight bolted joint, without any necessity of nut, after the simultaneous form drilling on the aluminium-steel pairs. The form drilling and threading are performed on the same machine tool that reduces the whole process time. The target markets for this approach are the light boiler making industry, in order to eliminate either welding beads or classical bolted joints using nuts [81].

While performing the experimental procedure, it should be noted that it is very difficult to calculate some of the material properties through experiments due to the lake of adequate laboratories and specialists to conduct those challenging experiments. It is difficult to obtain some material parameters of the model through experiments. Many organizations are now able to afford erstwhile privileged equipment like micro-hardness tester, scanning electron microscope, atomic force microscopy, etc. However, the development in the computational front will help to reduce the dependence on the experiment and will make it possible to simulate many experiments from the techniques like crystal plasticity finite element method [82]. Silva et al., 2014 [83], developed innovative testing machines and methodologies for the characterization of materials. Their work was mainly focused on the design, fabrication, and instrumentation of a flexible drop weight testing machine, an electromagnetic compressive Hopkinson bar, and an electromagnetic cam-driven compression testing machine that are capable of performing the mechanical characterization of 
materials under medium and high rates of loading. It was shown that the newly proposed electromagnetic cam-driven compression testing machine equipped with a root type cam profile can successfully replicate the operating conditions of the two other testing machines.

Alternative processes to conventional machining are increasing in various fields. The conventional material removal processes excessively affects the surface integrity and functional characteristics related to surface state, such as tensile strength. The use of unconventional machining processes like sheet metal forming and boiler making, abrasive waterjet AWJ, wire electro-discharge machining WEDM, laser and punching, could be used instead of the standardized milling process in order to obtain tensile specimens. There are two main advantages of using the alternative processes. The first advantage is that it shortens the time needed to produce tensile test specimens, and the second advantage is that the same technology finally applied in the final manufacturing step is used to prepare testing specimens [84]. During the process of carbon dioxide capture, storage and utilization, $\mathrm{CO}_{2}$ is transported by means of pipelines, with a variety of environmental conditions. The fatigue failure may be one of the possible causes of the pipeline's failure and should be taken into account during the long term planning of these processes [85-90]. The offshore pipelines can failed by a variety of failure mechanisms that include fatigue failure, corrosion failure, internal sheath damage etc. The enhanced Risk Based Inspection (RBI) methodology is an efficient way of certifying the integrity of steel pipeline [91-94].

Offshore jacket platform is most important in the oil and gas exploitation area, which provides production and living facilities for offshore drilling, production, construction and other activities. During the operation of offshore jacket platform at sea, it will be subjected to the periodic action of various loads, which will cause fatigue damage in the internal joints of the structure. To monitor the fatigue damage of structural joints, this paper studies the fatigue analysis method and fatigue crack development rules of typical joints of platforms through fatigue test and finite element analysis. The current study is based on engineering data of J225-IS oil field jacket platform in Bohai Bay, China. Bohai Bay is the largest offshore oil and gas production base in China, among those owned by the China National Offshore Oil Corporation (CNOOC). Based on the engineering data of J225-1S oil field jacket platform in Bohai Bay, three kinds of typical joints are selected in the current research, i.e., T-type plate joint, T-type tube-plate joint and T-type tube joint. Through the fatigue test of joints, the location of fatigue damage and the development of crack damage are observed and analyzed, and the fatigue life test results of joints are recorded. Combining with three kinds of typical joint specimens in fatigue test, this paper establishes the finite element analysis model, calculates, and analyzes the high stress and high strain regions, as well as fatigue damage distribution and fatigue life results of all kinds of joints. By comparing the results of finite element analysis with those of fatigue test, the fatigue damage and fatigue life prediction rules of joints using finite element method are summarized. The results show that the cracks of the three types of joints exist in the weld toe areas, but the fatigue life calculated by the finite element method is less than the experimental results, so the fatigue life prediction by the finite element method is reasonable and safe.

\section{Fatigue Test}

Fatigue strength has a scattering force specific to the four key parameters of the load, design, materials and manufacturing, so it is vital to evaluate the component using experimental tests [95]. JZ25-1S WHPA jacket located in Bohai Bay, China was used in the current study. Figure 1a shows the schematic diagram of JZ25-1S WHPA jacket. The real platform is shown in Figure 1b. The jacket has 6 main legs, 6 piles (the top pile leg of the catheter frame is $16 \mathrm{~m} \times 16 \mathrm{~m}$ and is underwater by 6 skirt piles), and 4 secondary legs and piles frame structure are used for supporting the topside weight. The water depths for jacket is 24 meters and the water depth at the side is $19.5 \mathrm{~m}$. The working point is at an elevation (EL) of $7.0 \mathrm{~m}$. The jacket has a tubular steel structure with six main legs and six through the leg piles. The jacket leg consists of two rows of 4 legs spaced at 40 meters to 
facilitate the floating over installation of the topside. Three horizontal framing levels are used at EL (+) $5.0 \mathrm{~m}, \mathrm{EL}(-) 8.0 \mathrm{~m}, \mathrm{EL}(-) 24.0 \mathrm{~m}$.

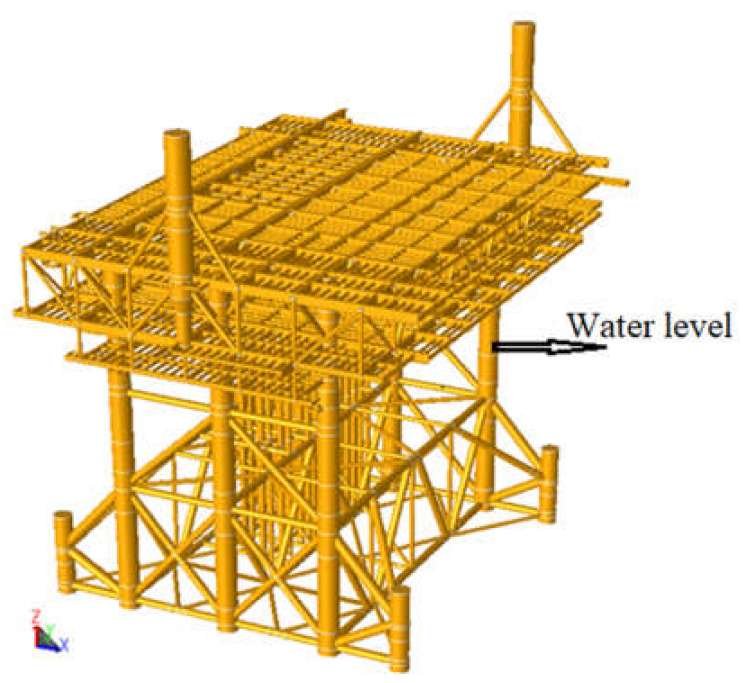

(a)

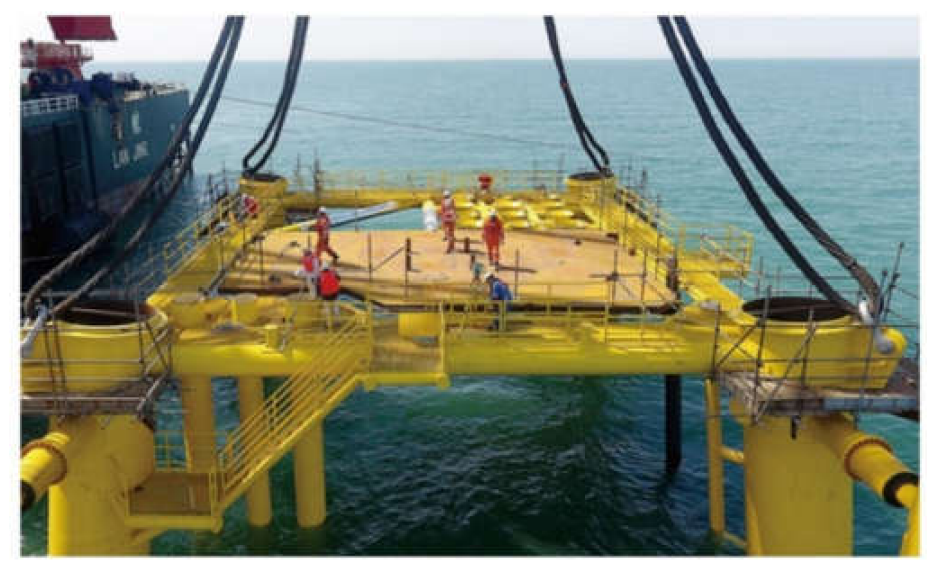

(b)

Figure 1. (a) Schematic diagram of JZ25-1S jacket; (b) real platform.

\subsection{Selection of Joints}

Fatigue damage of joints caused by harsh environmental conditions on JZ25-1S should be considered. The equipment and accuracy should also be taken into consideration when selecting the measurement method. Based on engineering report of manufacturing company, three types of specimens were used in laboratory measurements: the first one is T-type plate joint prepared by joining two metallic plates of different sizes in such a way that first plate is placed in vertical direction and second smaller plate is placed in horizontal direction and then welded as shown Figure 2a.

The second specimen is the combination of plate and pipe of T-type tube-plate joint prepared by joining a metallic plate and pipe of different sizes in such a way that the longer plate is placed in vertical direction while the smaller pipe is placed horizontally then welded as shown in Figure $2 b$.

The third specimen used in the testing is the combination of two metallic pipes of different sizes prepared by joining two metallic pipes in T-type joint in such way that the longer pipe is placed horizontally while smaller pipe is placed vertically and then welded as shown in Figure 2c. Furthermore, in Figure 3, the supports (mounts to the base) during the experimental fatigue tests are represented by blue color and the points and directions of the testing force are represented by red color. 


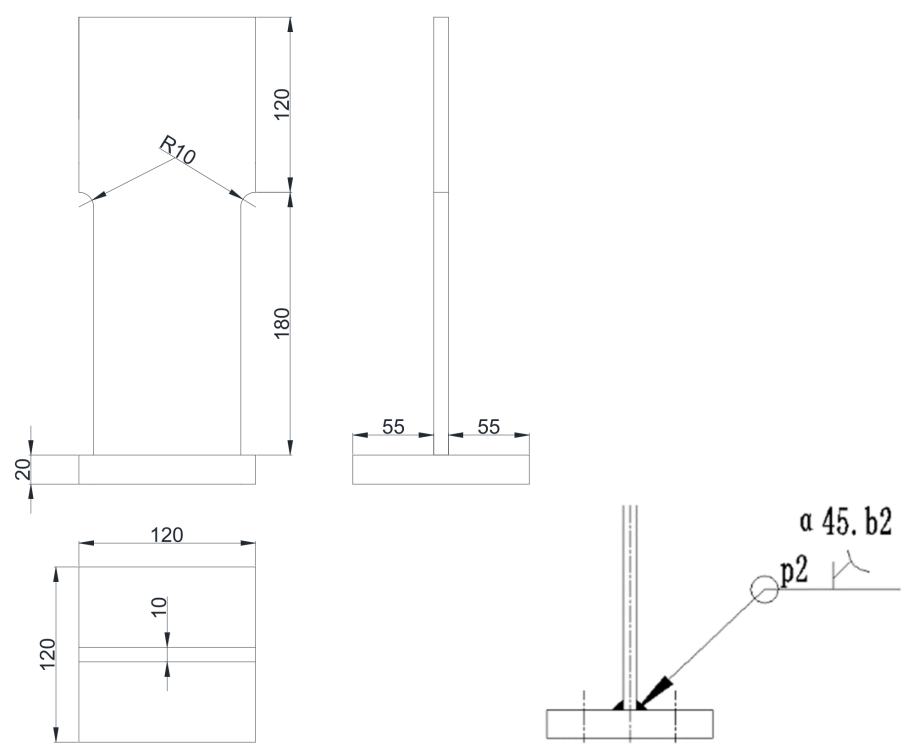

(a)

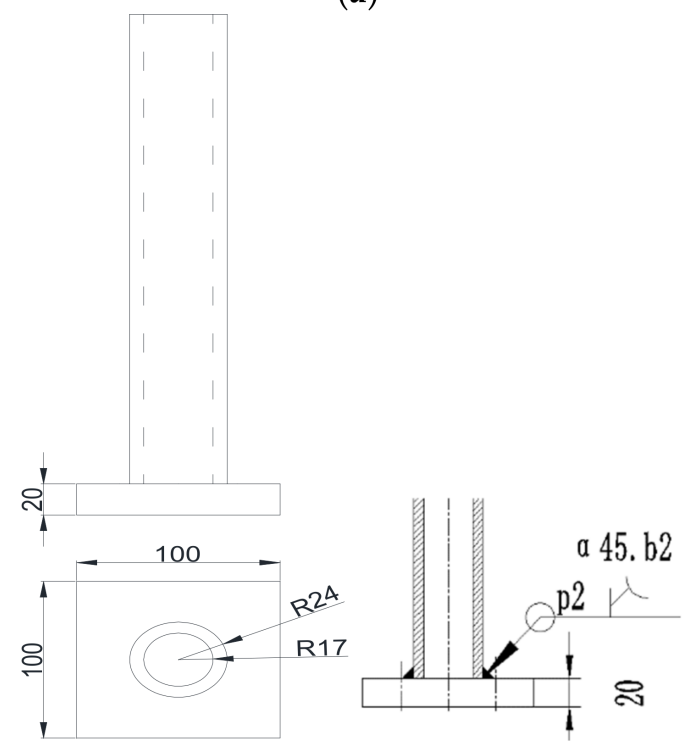

(b)
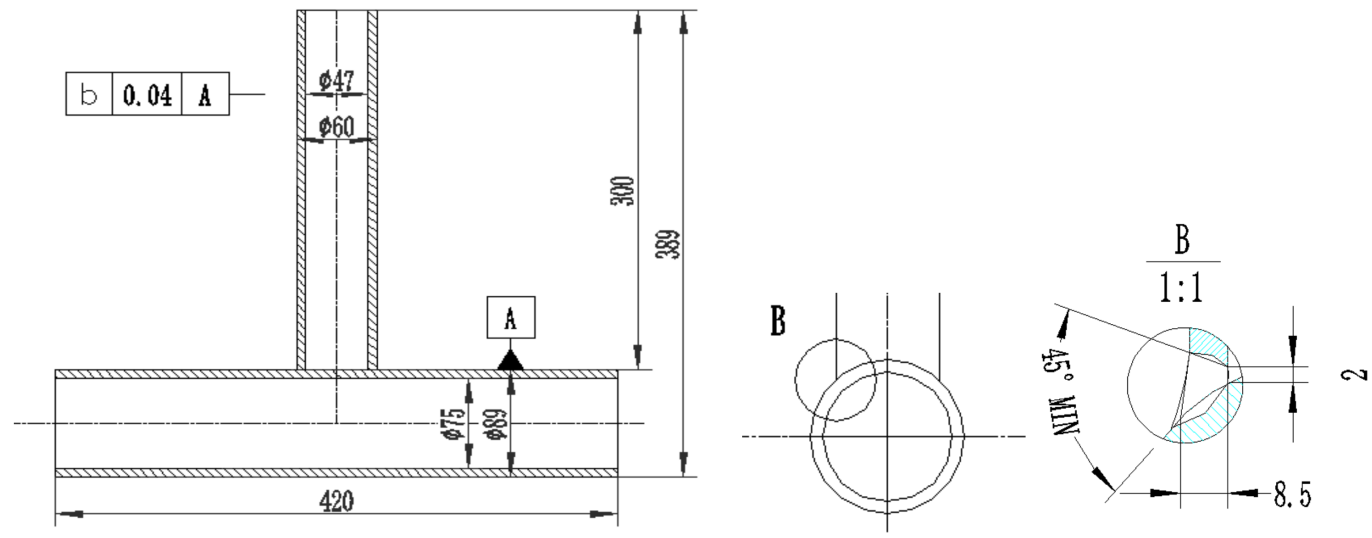

(c)

Figure 2. Geometry of the three types of specimens used in laboratory measurements. (a) T-type plate joint. (b) T-type tube-plate joint. (c) T-type tube joint. 


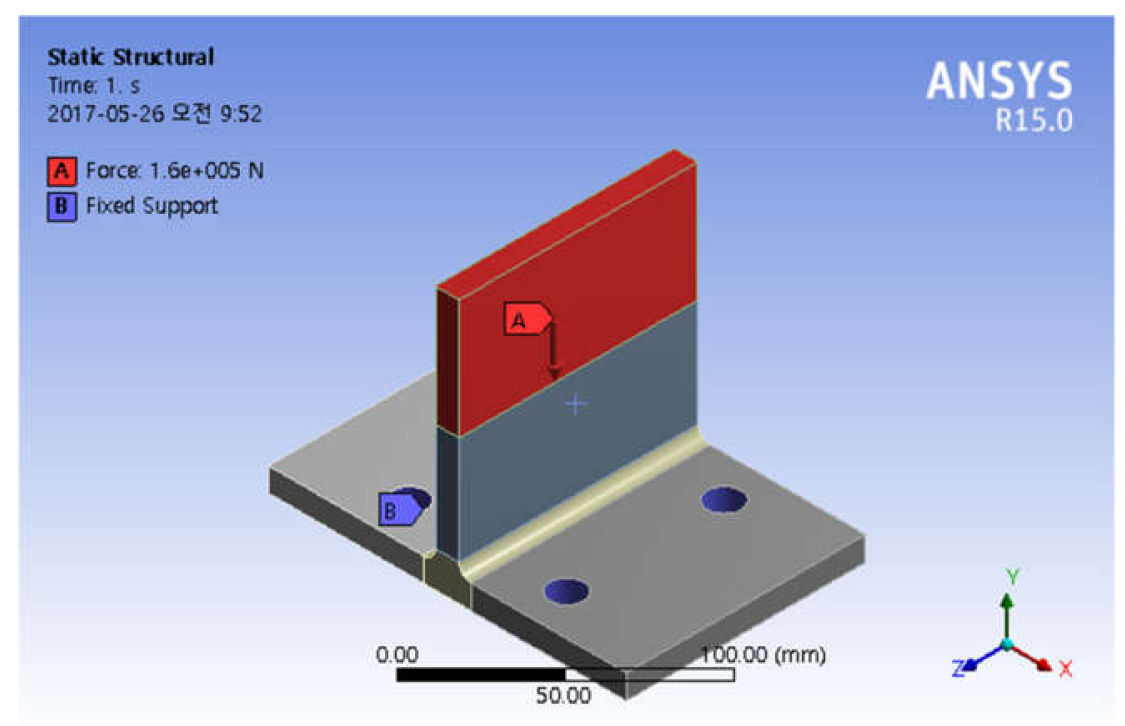

(a)

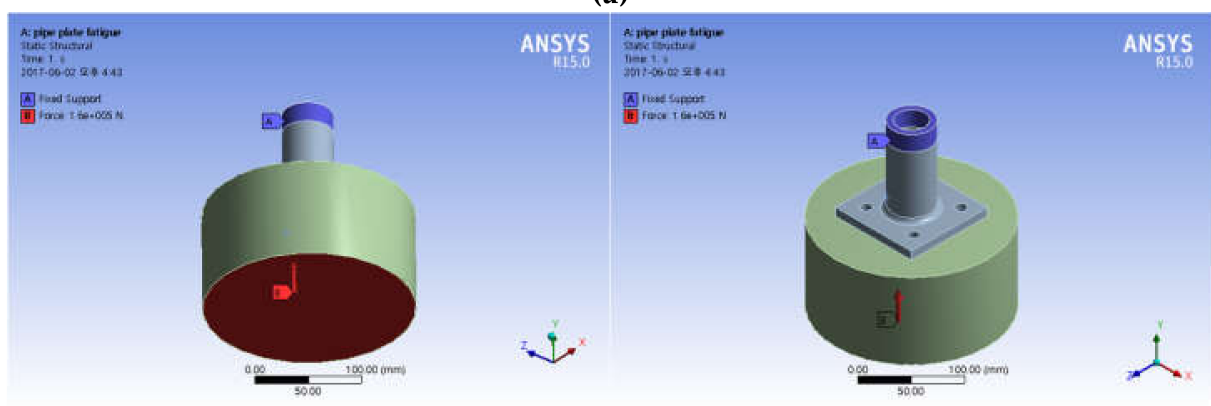

(b)

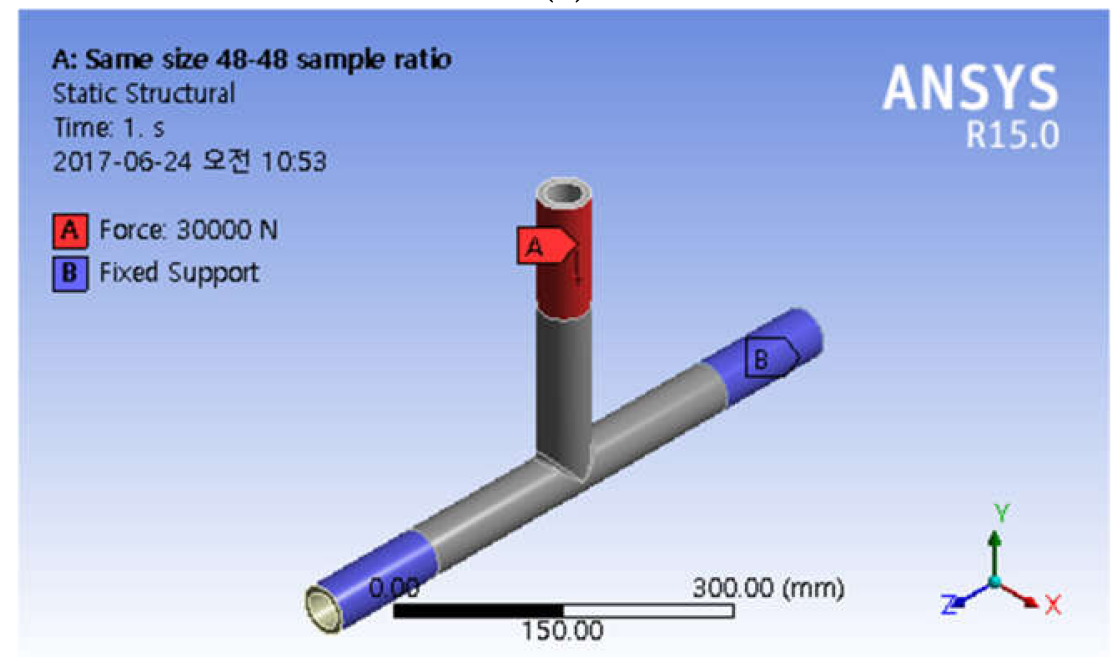

(c)

Figure 3. Supports and the points and directions of the testing force (a) for static structures (b) for pipe plate fatigue (c) for same size sample ratio.

Comprehensively considering the platform properties, production conditions, materials, equipment's loading conditions and capabilities, fatigue tests employ a relatively large load and refers to relevant specifications [96]. Mechanical properties of specimens are given in Table 1.

Carbon dioxide gas shield is used for welding the specimens. Before the parts were connected, the rust, oil stains, oxide scale and other substances harmful to welding on the surface of the steel parts were cleaned with an electric grinder. Appropriate preheating 
process must be used before steel plate welding to prevent hardened structure and cold cracks. The welding current should not be too large, and the welding speed should not be fast, otherwise it will cause slag removal that will be difficult to remove. The welding parameters are given in Table 2. The welding parameters are provided in ranges. The selection of the magnitudes of the weld parameters from a given range depends on the weld quality requirements while welding each of the specimens. The information about the heat input $[\mathrm{kJ} / \mathrm{mm}]$ is also provided in Table 2 . If there are defects such as pores and slag inclusions after welding, use an electric portable grinder to clean the defective part, and then repair it with manual arc welding. In order to eliminate the welding toe defects, after the specimen is welded, the welding undercut is polished to reduce the influence of the residual stress or the connection, and it is polished with a rotating grindstone. The Q345 steel was selected as the material for test in the current study. The material properties and chemical composition of the Q345 steel are given in Tables 1 and 3. Low alloy high strength steel Q345 is China GB standard steel and has good properties such as material density of $7.85 \mathrm{~g} / \mathrm{cm}^{3}$, tensile strength of $470-630 \mathrm{MPa}$, yield strength of $345 \mathrm{MPa}$, better than Q235 steel performance. Q345 steel is a low allowable structural steel with fine mechanical properties, low temperature performance, good welding and plasticity, Q345 steel is mainly used in low pressure containers, petroleum tanks, vans, large ships, mechanical components, offshore structures, and high load welded structural parts. The chemical composition of Q345B steel is given in Table 3. All around the world there are a number of other steel grades that are equivalent to the Q345B [97].

Table 1. Mechanical properties of specimens.

\begin{tabular}{cc}
\hline Property & Value \\
\hline Material types & Steel (Q345B) \\
Tensile strength (MPa) & $490-675$ \\
Yield strength (MPa) & $\geq 345$ \\
Elongation after fracture & $\geq 21 \%$ \\
\hline
\end{tabular}

Table 2. Welding parameters.

\begin{tabular}{ccccc}
\hline Specimen No & $\begin{array}{c}\text { Welding Current } \\
\text { [A] 50-100 }\end{array}$ & $\begin{array}{c}\text { Welding Voltage } \\
\text { [V] 18-21 }\end{array}$ & $\begin{array}{c}\text { Welding Speed } \\
{[\mathbf{m m} / \mathbf{s}] \mathbf{5 - 2 0}}\end{array}$ & $\begin{array}{c}\text { Heat Input } \\
{[\mathbf{k J} / \mathbf{m m}]}\end{array}$ \\
\hline \multirow{2}{*}{1} & 90 & 20.0 & 6.5 & 0.28 \\
& 75 & 19.0 & 5.0 & 0.29 \\
2 & 85 & 19.5 & 5.35 & 0.31 \\
& 94 & 20.5 & 6.5 & 0.30 \\
3 & 98 & 18.5 & 5.0 & 0.37 \\
& 88 & 21.0 & 6.18 & 0.30 \\
\hline
\end{tabular}

Table 3. Chemical composition of Q345B steel.

\begin{tabular}{cc}
\hline Elements & Content \\
\hline $\mathrm{C} \leq$ & 0.2 \\
$\mathrm{Mn}$ & $1.0-1.6$ \\
$\mathrm{Si} \leq$ & 0.035 \\
$\mathrm{Al} \geq$ & $0.02-0.15$ \\
$\mathrm{Nb}$ & $0.015-0.06$ \\
\hline
\end{tabular}

\subsection{Experimental Process}

The complete experimental process is shown in Figure 4. The experimental setup is located in the Marine Engineering Experimental Institute at Zhejiang University. During the start of the experiment, the piezoelectric transducers are first attached to the four different specimens as shown in Figure 5. The specimens are then loaded in the load frame machine, 
shown in Figure 4. The impedance analyzer was used to check the specimen twice, before applying any load, in order to avoid any possible errors in the results. For detecting cracks in the specimen, a penetration test is applied and the specimen is also analyzed using a digital microscopic camera. The presence of the crack is shown on the computer screen with the help of the VEE Pro software. The experimental procedure is designed based on the guidance provided in the ASTM E466-15 standard force-controlled fatigue tests, ASTM E647-15e1 standard for measurement of fatigue crack growth rates, E739-10(2015) standard for statistical analysis of linear or linearized stress-life (S-N) and strain-life $(\varepsilon-N)$ fatigue data and E1049-85(2017) standard for cycle counting in fatigue analysis.

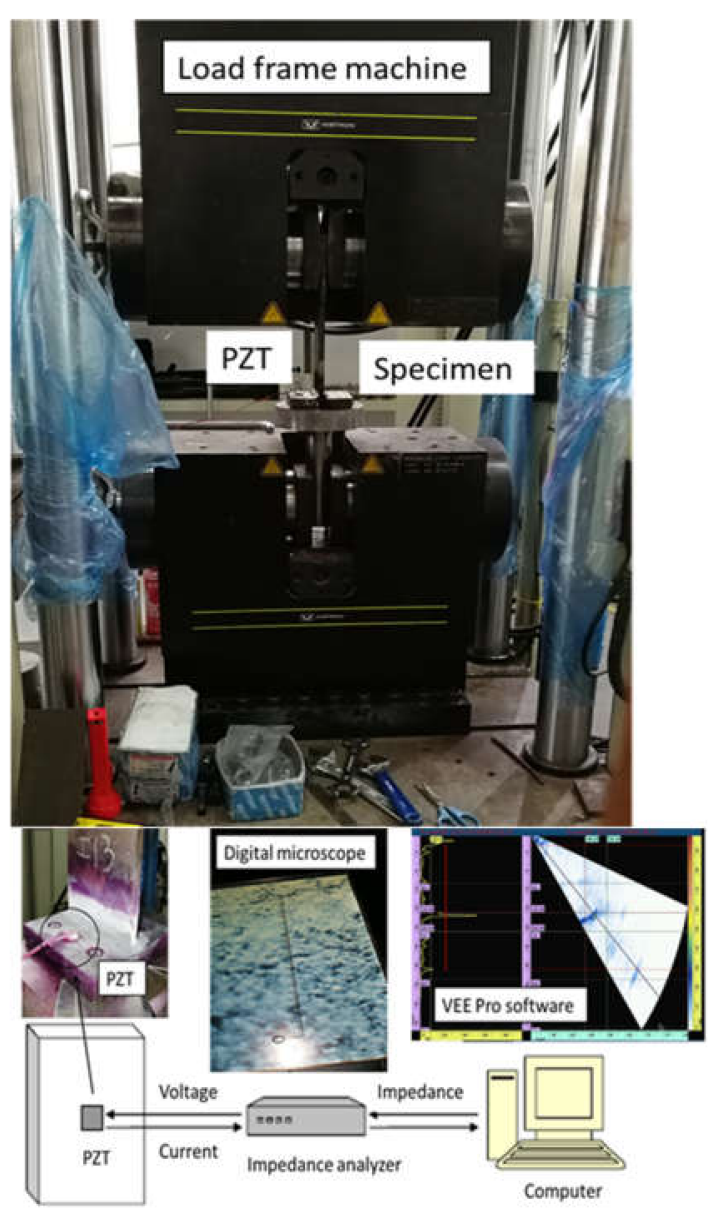

Figure 4. Experimental setup.

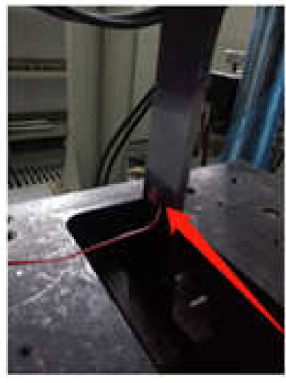

T-type welded

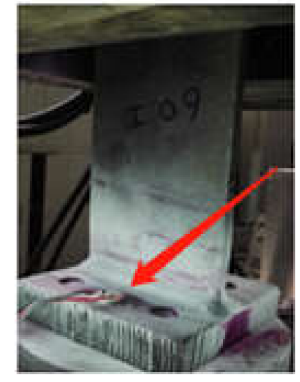

T-type plate

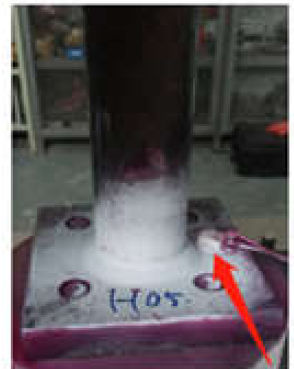

T-type tube-plate

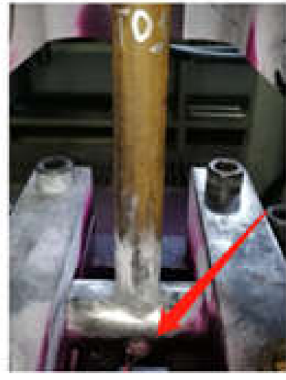

T-type tube metallic plate

Figure 5. PZT transducers mounted on the specimens. 
The cyclic load from the load frame is continuously applied on the specimen until the crack is detected. In order to create a more visible surface of specimen for detecting the crack, the DPT- 8 dye penetrate inspection material is used to perform the penetration test. The presence of the damage in the specimen will affect the sensitivity of the PZT. PZT is pasted near the welded zone in the case of T-type specimens, in order to achieve better impedance results at the welded zone. The cracks were detected and the damage locations were specified in all the specimens using the microscopic camera.

\subsection{Experimental Results}

After completing the calibration and preloading of the fatigue testing machine, fatigue test on the specimens were performed. Different specimens are observed and recorded on different regular intervals.

The test results of the three types of joints are relatively different, and the reasons are as follows:

(1) Due to the difference in welding quality, the welding strength of each specimen is different. The differences in the quality of the tested joints is mainly dependent on the welding quality.

(2) The crack damage location is different. Some are in the weld area, and some are outside the weld area.

(3) Due to the existence and influence of the initial defects of the specimen, the experimental results have a certain degree of uncertainty.

(4) The fatigue crack damage observed in the experiment may be at different stages.

(5) In the current study, the cracks were mainly detected in the heat-affected zone.

Based on the experimental study performed in this paper, the following suggestions are listed for fatigue tests in future research:

(1) When making fatigue specimen, the welding conditions and quality of the specimens should be strictly controlled to ensure the consistency of the specimen performance.

(2) Different types and positions of structural damage may have an impact on the fatigue results.

(3) The impact of initial defects on the structure should be reduced as low as possible.

(4) High-precision and sensitive fatigue crack observation devices are suggested to be applied in order to improve the accuracy of observations.

\subsubsection{T-Type Plate Joint}

During the fatigue loading process of the T-type plate joint, the lower bottom plate was fixed on the base of the test bench by bolts, and the other end was clamped on the fixture that apply periodic cyclic load. The loading frequency was $1 \mathrm{~Hz}$ and magnitude was $150 \mathrm{kN}$. The testing machine was loaded from $-150 \mathrm{kN}$ to $+150 \mathrm{kN}$. The load value used in the experiment is much larger than the actual operating conditions, with the aim of producing fatigue cracks within a limited experimental time.

The damage and cracks were observed and monitored under certain period. Once the fatigue crack damage was detected, the loading was stopped, and the number of loading cycles at that time was recorded. Crack location and damage situation of T-type plate joint were observed, the results are summarized in Table 4.

Due to the fluctuation of the fatigue life observed in the tests, the average fatigue life is selected in this paper. The available fatigue life of welded metallic plate joint is 16,402 times. As shown in Figure 6, the fatigue cracks of T-type plate joint often occur in the weld toe area on the joint connection part. The damage location of the weld toe is more concentrated in the location near the edge of the side corner. It can be seen that fatigue crack damage is prone to be shown in the upper welding toe of the joint connection weld, especially the area near the edge corner, which should also be the focus in the engineering practice. 
Table 4. Test results of T-type plate joint.

\begin{tabular}{ccccc}
\hline Specimens & Load (kN) & $\begin{array}{c}\text { Fatigue Life } \\
\text { (Times) }\end{array}$ & Damage Position & $\begin{array}{c}\text { Crack Length } \\
\text { (mm) }\end{array}$ \\
\hline G01 & 150 & 9409 & Weld toe & 13.500 \\
G02 & 150 & 6666 & Weld toe & 9.760 \\
G03 & 150 & 5361 & Weld seam & Large crack \\
G04 & 150 & 976 & Weld seam & Large crack \\
G05 & 150 & 4714 & Weld toe & 1.360 \\
G06 & 150 & 10,017 & Weld toe & 2.816 \\
G07 & 150 & 6937 & Weld toe & 5.390 \\
G08 & 150 & 2894 & Bolt & Large crack \\
G09 & 150 & 3450 & Weld toe & 2.254 \\
G10 & 150 & 17,114 & Weld toe & 0.463 \\
G11 & 150 & 24,202 & Weld toe & 8.386 \\
G12 & 150 & 43,279 & Weld toe & 6.850 \\
G13 & 150 & 62,441 & Weld toe & Large crack \\
G14 & 150 & 32,177 & Weld toe & 1.038 \\
\hline
\end{tabular}

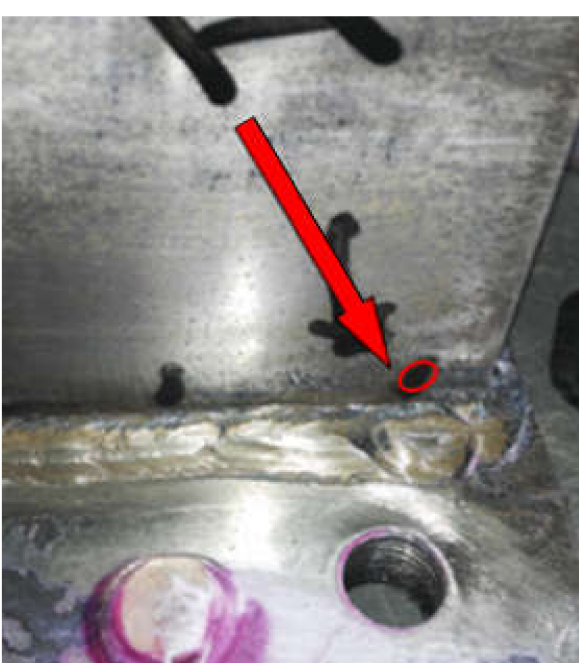

(a)

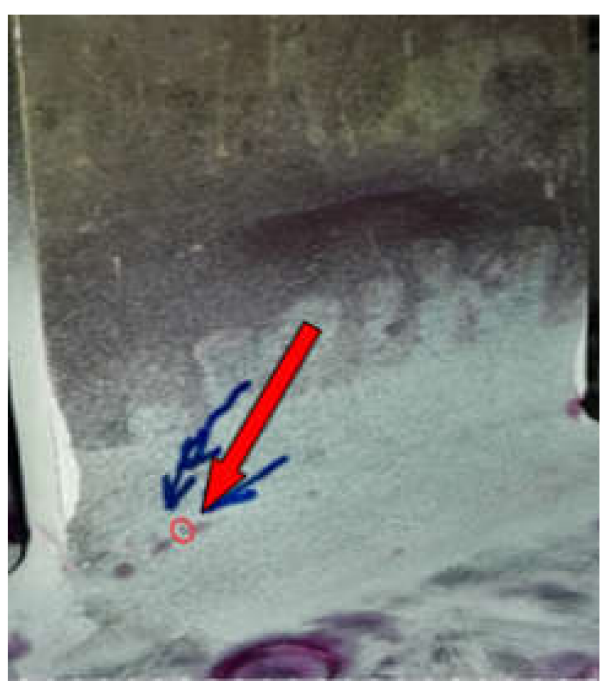

(c)

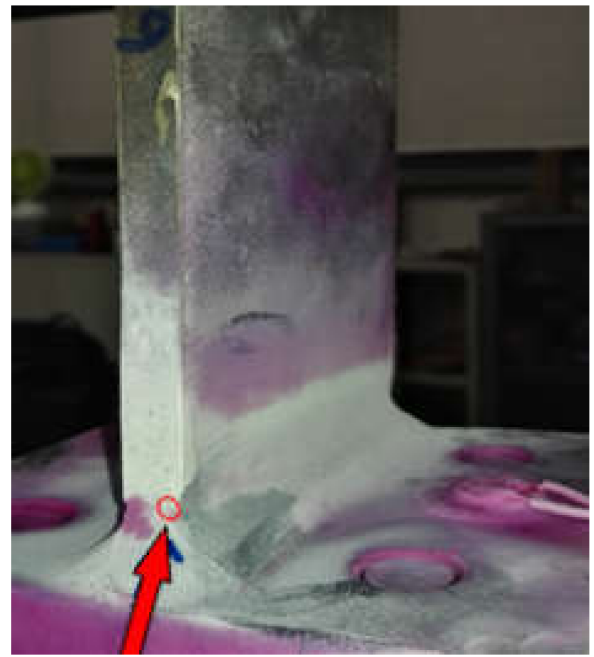

(b)

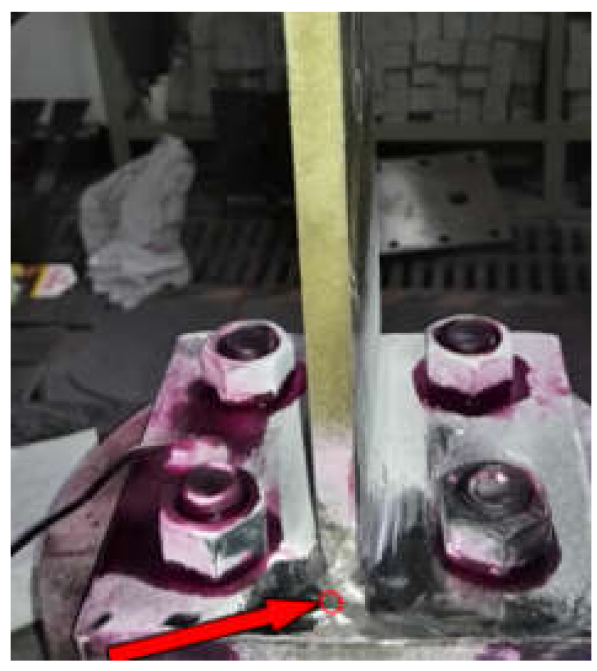

(d)

Figure 6. Cracks locations on T-type welded metallic plate (a) at upper welding toe (b) near the edge corner (c) on the weld toe (d) near side edge corner. 
While observing the fatigue crack damage of the specimens, the early fatigue cracks of the typical joints can be found. Taking G10 as an example, when sub-millimeter crack is shown in the microscopic observation, open the test machine dynamic loading. The crack develops from $0.463 \mathrm{~mm}$, gradually expanding to $0.687 \mathrm{~mm}$, and then growing to over $1.846 \mathrm{~mm}$.

In the process of gradual expansion and extension, it can be seen that the cracks change from a simple straight line at the initial stage of small microcracks to a bent and broken line shape. On the other side, some cracks appeared in other areas were observed. As the fatigue loading continued to apply, obvious fatigue fractures appeared at the welds and the edges of the base metal, as shown in Figure 7.

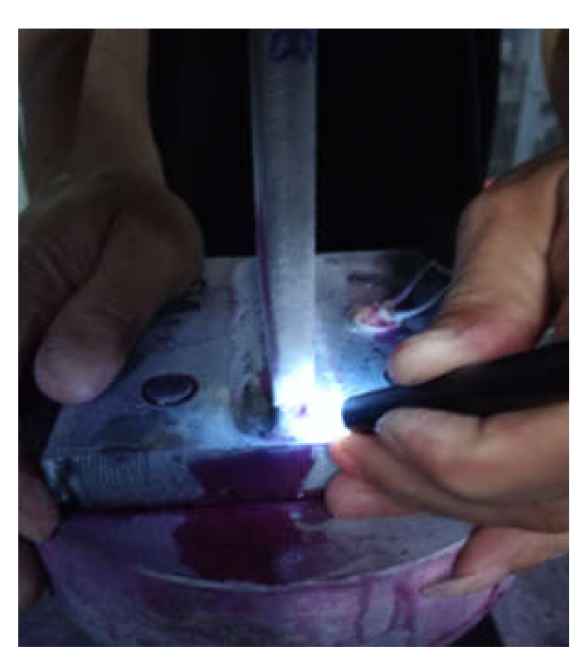

(a)

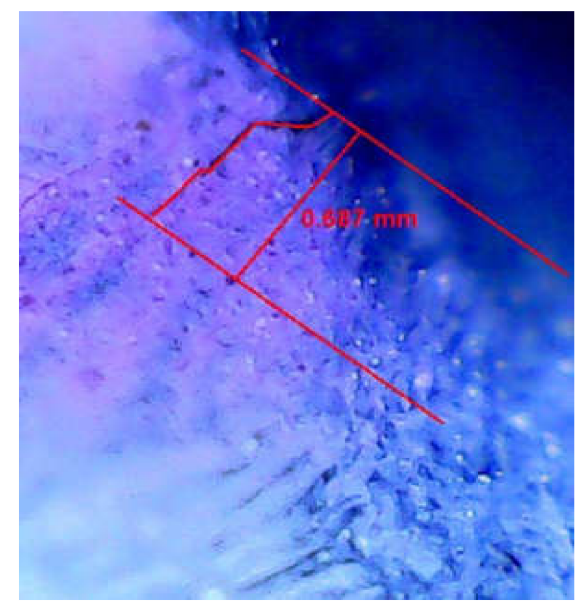

(c)

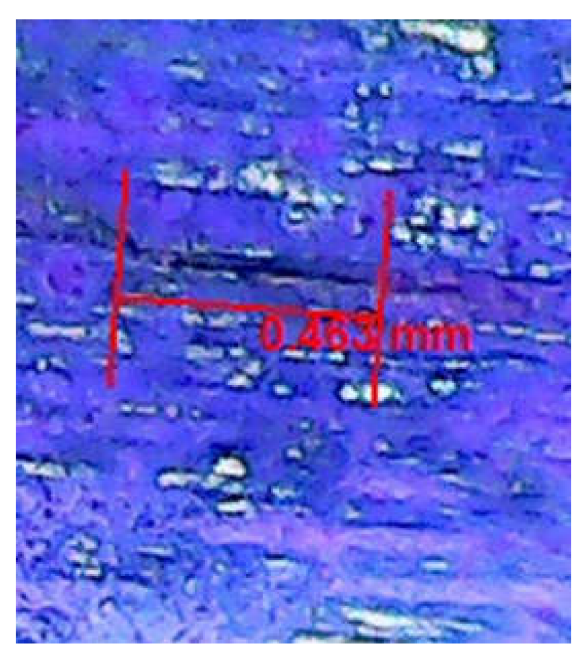

(b)

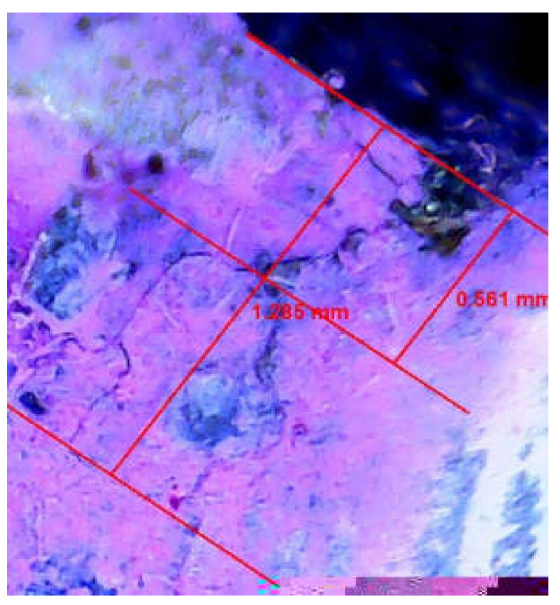

(d)

Figure 7. Microscopic observation of fatigue crack in T-type plate joint (a) cracks initiated at edges of the base metal (b) observed crack of $0.463 \mathrm{~mm}$ length (c) observed crack of $0.687 \mathrm{~mm}$ length (d) observed cracks of $0.561 \mathrm{~mm}$ and $1.285 \mathrm{~mm}$ lengths.

\subsubsection{T-Type Tube-Plate Joint}

The loading frequency of T-type tube-plate joint test was $1 \mathrm{~Hz}$ and magnitude was $150 \mathrm{kN}$. The testing machine is loaded from $-150 \mathrm{kN}$ to $+150 \mathrm{kN}$. The load value used in the experiment is much larger than the actual operating conditions, with the aim of producing fatigue cracks within a limited experimental time.

The damage and cracks were observed and monitored under certain period, and the results were summarized in Table 5 . As shown in Table 5, in the current study, cracks were also observed in the welds. 
Table 5. Test results of T-type tube-plate joint.

\begin{tabular}{ccccc}
\hline Specimens & Load (kN) & $\begin{array}{c}\text { Fatigue Life } \\
\text { (Times) }\end{array}$ & Damage Position & $\begin{array}{c}\text { Crack Length } \\
\text { (mm) }\end{array}$ \\
\hline H01 & 150 & 3553 & Near weld seam & 9.940 \\
H02 & 150 & 1400 & Bolt cracked & 12.680 \\
H03 & 150 & 2350 & Weld seam cracked & Snapped \\
H04 & 150 & 5491 & Weld seam & 13.000 \\
H05 & 150 & 12,446 & Weld toe & 4.200 \\
H06 & 150 & 8393 & Weld toe & 1.050 \\
H07 & 150 & 10,758 & Weld toe & 3.468 \\
H08 & 150 & 2465 & Weld toe & 0.920 \\
H09 & 150 & 17,167 & Weld toe & 14.640 \\
H10 & 150 & 5429 & Weld toe & 0.559 \\
H11 & 150 & 15,491 & Weld seam cracked & Snapped \\
H12 & 150 & 28,841 & Weld toe & 2.480 \\
H13 & 150 & 21810 & Weld toe & 10.129 \\
H14 & 150 & 30391 & Snaped & Large crack \\
\hline
\end{tabular}

In order to reduce the error, the average fatigue life is selected as the test results in this paper. The available fatigue life of T-type tube-plate joint is 11,856 times. The fatigue cracks of T-type tube-plate joint often occurred in the weld area of the tube-plate connection. Most cracks appeared in the upper weld toe part of the connecting zone, as shown in Figure $8 \mathrm{a}, \mathrm{b}$, and a small number of fatigue cracks appeared in the lower weld toe, as shown in Figure $8 \mathrm{c}$,d. Therefore, attention should be paid to the weld toe of the connection zone, especially the upper weld toe area.

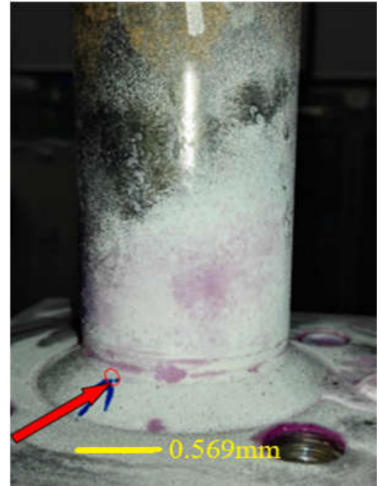

(a)

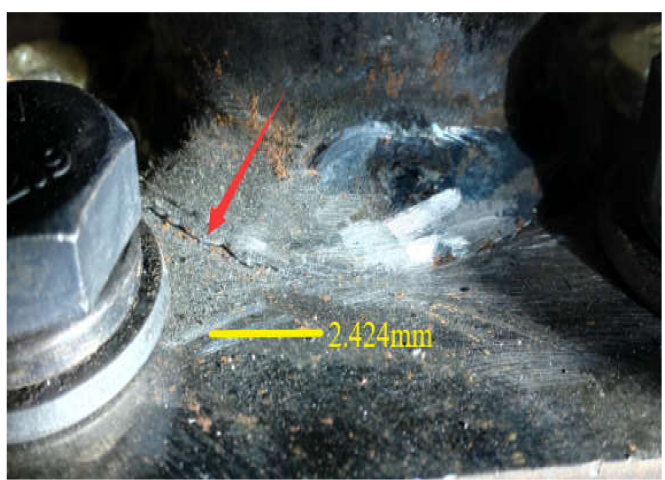

(c)

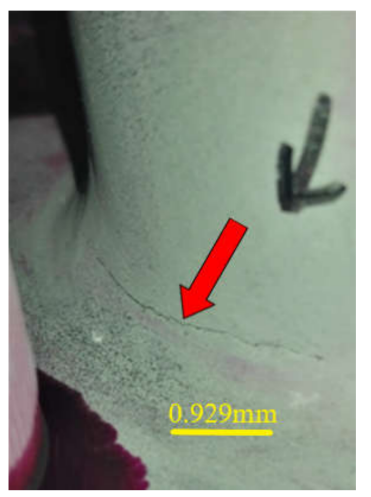

(b)

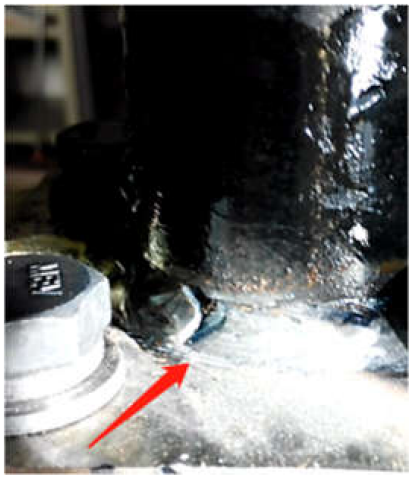

(d)

Figure 8. Cracks of T-type tube-plate joint (a) observed crack of $0.569 \mathrm{~mm}$ length (b) observed crack of $0.929 \mathrm{~mm}$ length (c) observed crack of $2.424 \mathrm{~mm}$ length (d) large crack initiated at edges of the base metal. 
H10 specimen was continuously loaded after recording the corresponding fatigue cycles when the fatigue crack appears. As shown in Figure 9, a small $0.559 \mathrm{~mm}$ submillimeter crack, like a straight line is first observed. Then the crack is expanded to $0.929 \mathrm{~mm}$ after 1000 cycles, growing later on to nearly $2.424 \mathrm{~mm}$. In the process of crack propagation, the shape of the crack mainly changes linearly. With an increase in the number of loading, the fatigue crack has a relatively obvious growth, and gradually expands to a larger visible scale.

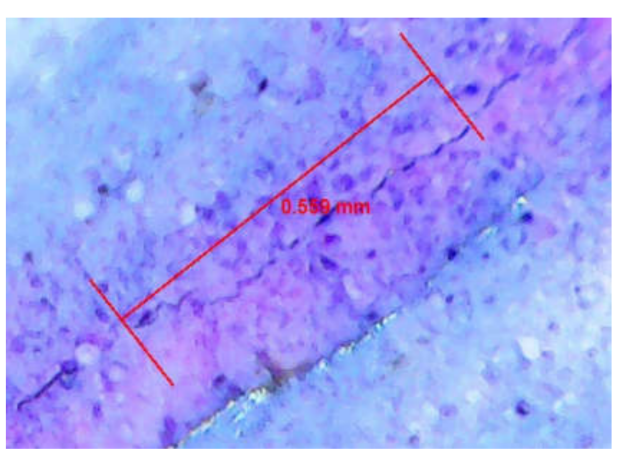

(a)

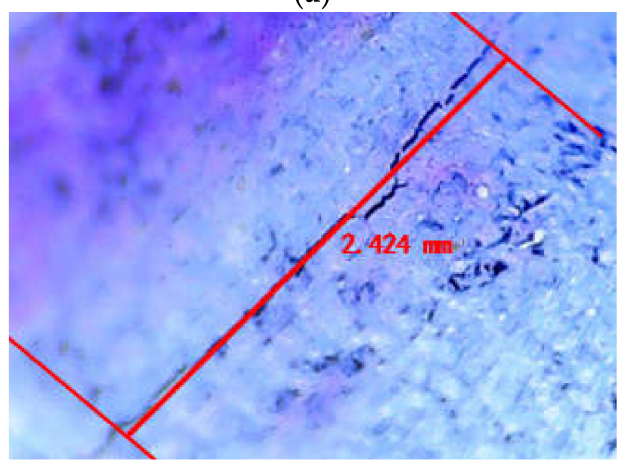

(c)

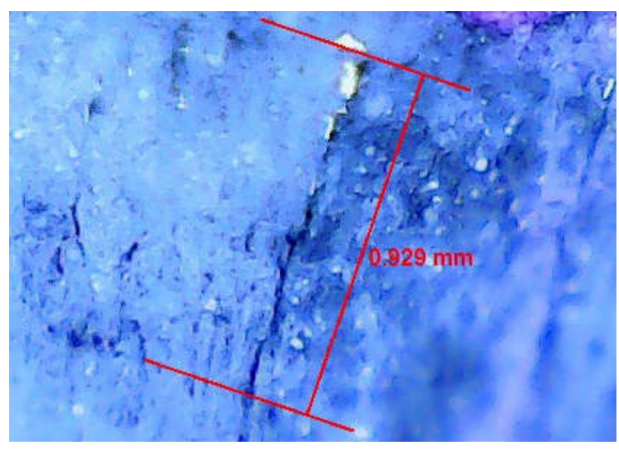

(b)

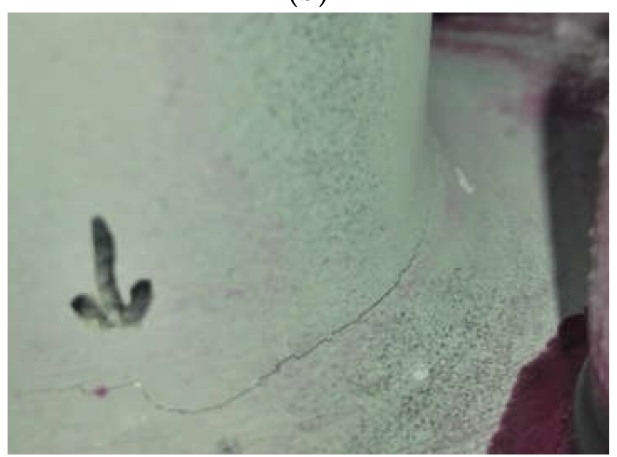

(d)

Figure 9. Microscopic observation of fatigue crack in T-type tube-plate joint (a) observed crack of $0.559 \mathrm{~mm}$ length (b) observed crack of $0.929 \mathrm{~mm}$ length (c) observed crack of $2.424 \mathrm{~mm}$ length (d) cracks initiated at edges of the base metal.

\subsubsection{T-Type Tube Joint}

The loading frequency of T-type tube joint test was $1 \mathrm{~Hz}$ and magnitude was $180 \mathrm{kN}$. The testing machine was loaded from $-180 \mathrm{kN}$ to $+180 \mathrm{kN}$. As compared to the other two types of joints, the load magnitude is more due to the size of the weld section. The damage and cracks were observed and monitored under certain period, and the results are summarized in Table 6.

Table 6. Test results of T-type tube joint.

\begin{tabular}{ccccc}
\hline Specimens & Load $\mathbf{( k N )}$ & $\begin{array}{c}\text { Fatigue Life } \\
\text { (Times) }\end{array}$ & $\begin{array}{c}\text { Damage } \\
\text { Position }\end{array}$ & $\begin{array}{c}\text { Crack Length } \\
(\mathbf{m m})\end{array}$ \\
\hline T01 & 180 & 638 & Outside weld toe & 12.470 \\
T02 & 180 & 337 & Weld toe & 8.984 \\
T03 & 180 & 794 & Weld toe & 4.247 \\
T04 & 180 & 618 & Weld toe & 0.864 \\
T05 & 180 & 529 & Weld toe & 3.766 \\
T06 & 180 & 224 & Weld toe & 2.443 \\
T07 & 180 & 321 & Weld toe & 4.596 \\
T08 & 180 & 132 & Weld toe & 0.947 \\
\hline
\end{tabular}


In order to reduce the error, the average fatigue life is selected as the test results in this paper. The available fatigue life of T-type tube joint is 449 times. As shown in Figure 10, the fatigue cracks of T-type tube joint often occurred in the weld area of the tube-tube connection. Crack damage often occurred in the upper and lower toe areas and extended along the welding direction. T-type tube joints are relatively common in jacket platforms. As one of the main structural components, it is necessary to focus on the weld area, especially the upper and lower welding toe, should be carefully inspected and monitored in the engineering practice.

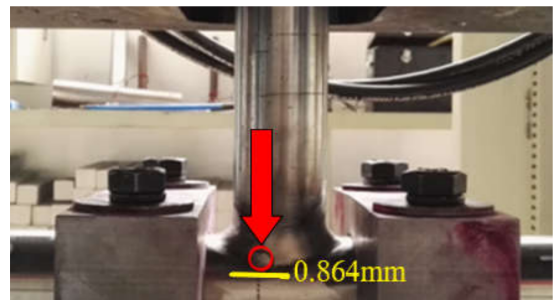

(a)

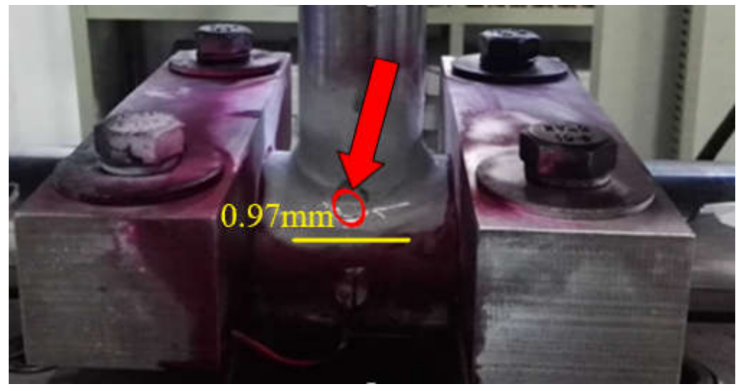

(b)

Figure 10. Cracks of T-type tube joint (a) observed crack of $0.864 \mathrm{~mm}$ length (b) observed crack of $0.970 \mathrm{~mm}$ length.

Figure 11a shows the first fatigue crack observed $(0.864 \mathrm{~mm})$ during the test, which is a linear crack. As the fatigue loading continues, the crack expands in a linear shape, and new cracks are also generated, as shown in Figure 11b.

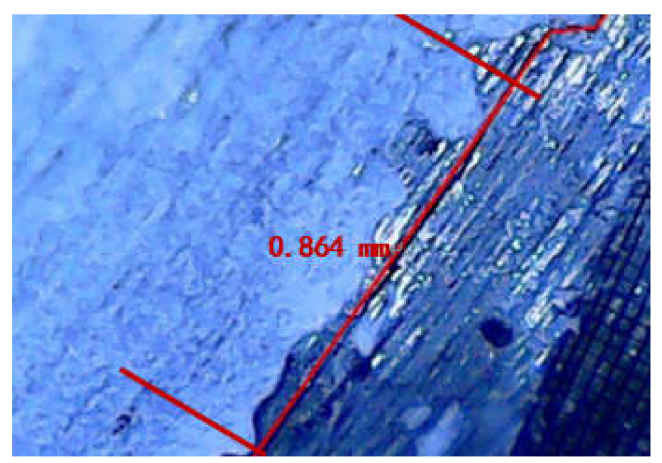

(a)

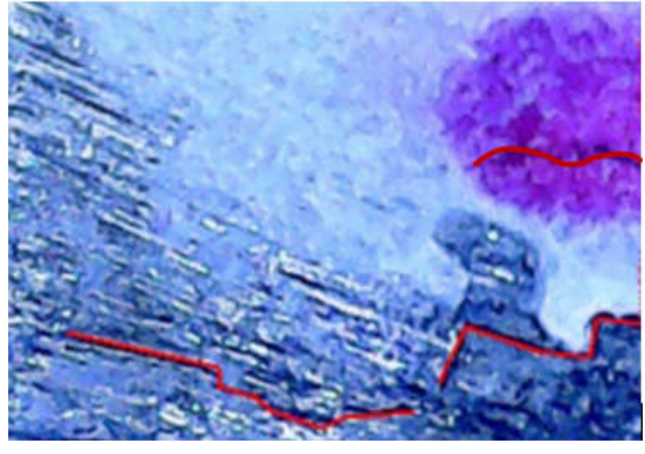

(b)

Figure 11. Microscopic observation of fatigue crack in T-type tube joint (a) observed crack of $0.864 \mathrm{~mm}$ length (b) cracks initiated at edges of the base metal.

\section{Finite Element Analysis \\ 3.1. Modelling}

Referring to the typical joints that have completed the fatigue test in Section 2, finite element models were established, and stress analysis was carried out using ANSYS to study the fatigue life prediction. The three-dimensional modeling software SolidWorks was used to establish the three-dimensional model of specimens and welded seam. Since the welds of specimens were all polished after welding, the weld geometry is consistent with the actual weld seam, as shown in Figure 12. Shared nodes were used to connect the welded seam and base metal.

The materials of three the typical joints are all Q345 steel. The performance parameters of Q345 are shown in Table 7. 


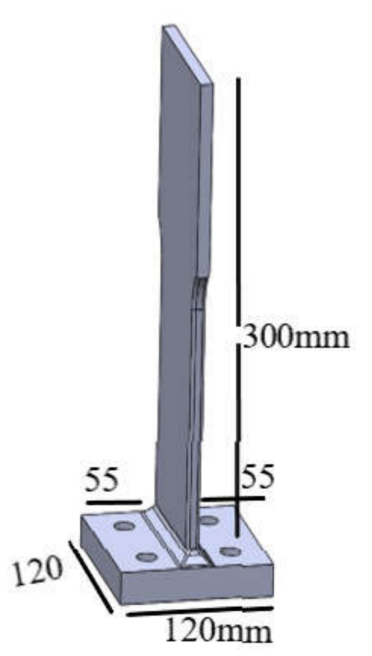

(a)

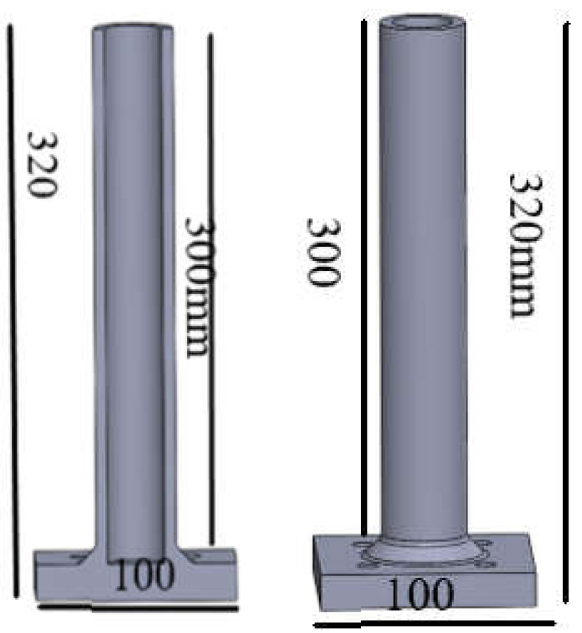

(b)
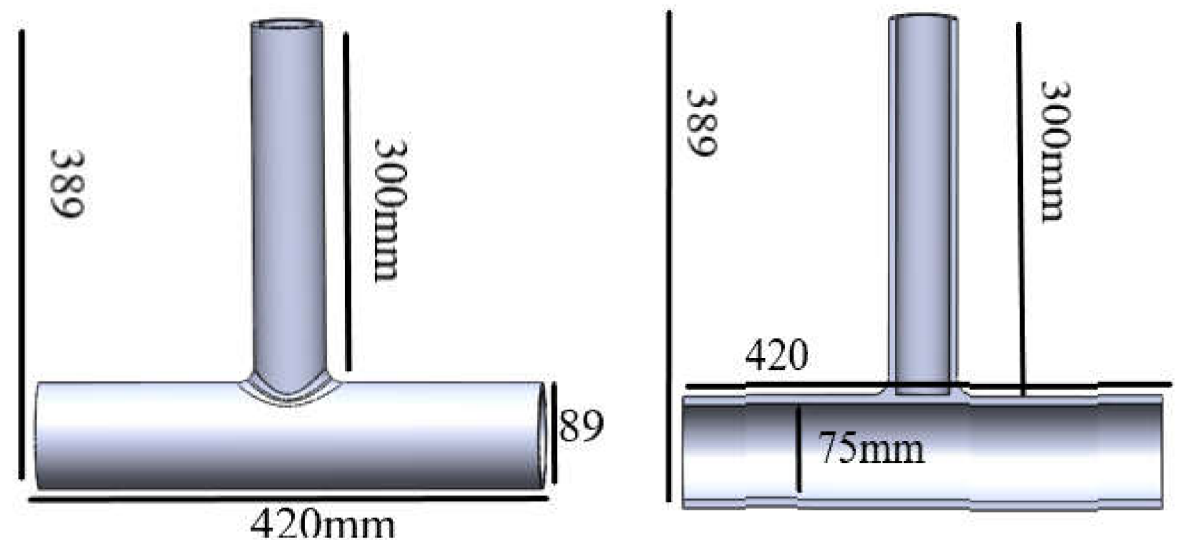

(c)

Figure 12. Finite element models of three typical joints (a) T-type plate joint (b) T-type tube-plate joint (c) T-type tube joint.

Table 7. Performance parameters of Q345.

\begin{tabular}{ccccc}
\hline Material & $\begin{array}{c}\text { Young's } \\
\text { Modulus (GPa) }\end{array}$ & Poisson Ratio & $\begin{array}{c}\text { Tensile } \\
\text { Strength (MPa) }\end{array}$ & $\begin{array}{c}\text { Yield Point } \\
\text { (MPa) }\end{array}$ \\
\hline Q345 & 206 & 0.28 & 550 & 320 \\
\hline
\end{tabular}

\subsection{Mesh}

The geometric models of the three typical joints have symmetrical characteristics. Therefore, the 1/4 model can be used in the finite element analysis, which can reduce computational costs and improve the efficiency and accuracy of finite element calculation.

The hexahedral mesh with Solid 186 elements was used, which are second-order elements. Compared with linear elements, it has more integration points so that the results are more accurate. The welds are locally refined, and the mesh model information of each joint is shown in Table 8. 
Table 8. Mesh information of each joint.

\begin{tabular}{cccc}
\hline Type & Grid Size $\mathbf{( m m )}$ & $\begin{array}{c}\text { Number of Grid } \\
\text { Elements }\end{array}$ & $\begin{array}{c}\text { Number of Grid } \\
\text { Nodes }\end{array}$ \\
\hline T-type plate joint & 2 & 60148 & 266232 \\
T-type tube-plate joint & 2 & 69457 & 307746 \\
T-type tube joint & 2 & 43546 & 211881 \\
\hline
\end{tabular}

\subsection{Boundary Conditions and Applied Load}

In the analysis, the constrained boundary of the finite element model is to simulated installation of specimens on the fatigue bench. Detailed boundaries and loads are described as follow:

(1) T-type plate joint: the boundary conditions are set as shown in Figure 13a. The A end is fixed and the B end is loaded.

(2) T-type tube-plate joint: the boundary conditions are set as shown in Figure 13b. The A end is fixed, and the B end is loaded.

(3) T-type tube joint: The boundary conditions are set as shown in Figure 13c. Both sides of the lower pipe are fixed to simulate clamping, and the B end is loaded.

The load application is also consistent with the fatigue test. When the finite element model is a $1 / 4$ symmetric model, the load is also $1 / 4$ of the total load. The load application of each joint is shown in Table 9 .

A Fixed Support Force: $37500 . \mathrm{N}$

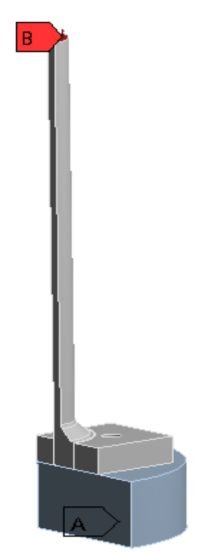

(a)

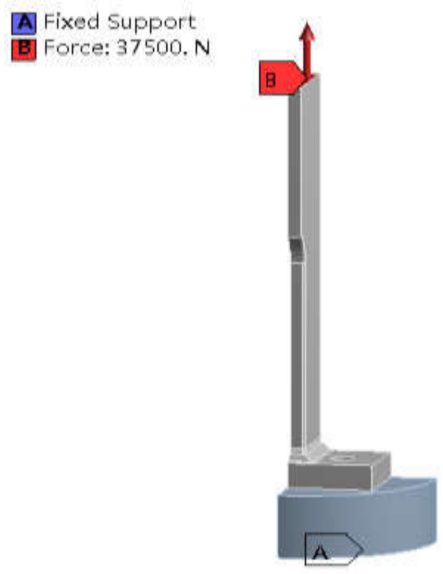

(b)

ixed Support

Force: $47500 . \mathrm{N}$

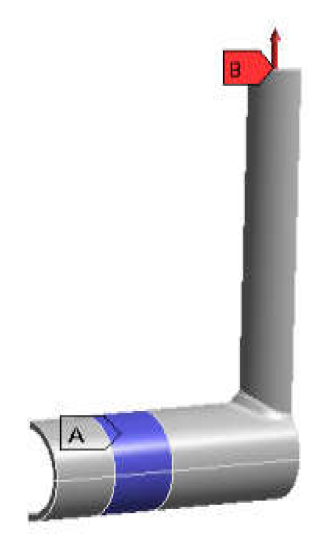

(c)

Figure 13. Boundary condition of each joint (a) T-type plate joint (b) T-type tube-plate joint (c) T-type tube joint. 
Table 9. Loads for each joint type.

\begin{tabular}{cccc}
\hline Type & $\begin{array}{c}\text { Finite Element } \\
\text { Model }\end{array}$ & Test Load (N) & Simulative Load (N) \\
\hline T-type plate joint & $1 / 4$ model & 150,000 & 37,500 \\
T-type tube-plate joint & $1 / 4$ model & 150,000 & 37,500 \\
T-type tube joint & $1 / 4$ model & 180,000 & 47,500 \\
\hline
\end{tabular}

\subsection{S-N Curve}

Fatigue strategy of offshore structures is founded on the S-N curves obtained from tubular joint testing, where faults are defined as wall thickness penetration [96,97]. However, in practice, fatigue cracks are probable to continue to raise around the welding environment after cracking through the walls, and in some cases, significant residual life has been found after cracking through thickness [98-102]. Most fatigue calculations are carried out from the S-N curves. These curves have been shown to be a proper decent approximation of fatigue life. S-N is a short form for stress and period/cycle (N), respectively [103]. The S-N curve is usually best suited for high cycle fatigue, where the strain remains within the elastic range. The low-cycle fatigue often causes stress in the plastic range and is best described using a strain-based approach [103].

The S-N curve uses the fatigue strength of the standard specimen as the ordinate, and the logarithm of the fatigue life as the abscissa, which represents the relationship between the fatigue strength and fatigue life of the standard specimen under certain cycle characteristics. The S-N curves need to be selected before finite element simulation. The fatigue S-N curve formula is defined as follows:

$$
\begin{gathered}
\log N=\log \overline{\mathbf{a}}-\operatorname{mlog}\left(\Delta \sigma\left(\frac{\mathbf{t}}{\mathbf{t}_{\text {ref }}}\right)^{\mathbf{k}}\right) \\
\log \overline{\mathbf{a}}=\log \mathbf{a}-2 S_{\log N}
\end{gathered}
$$

where $\mathrm{N}$ is the fatigue life under stress amplitude $\Delta \sigma$ (unit: times), $\mathrm{m}$ is the slope of the $\mathrm{S}-\mathrm{N}$ curve, $\log \overline{\mathrm{a}}$ is the intercept of the curve on the logarithmic $\mathrm{N}$ axis, $\log \mathrm{a}$ is the intercept of average S-N curve, $S_{\log N}$ is the standard deviation of the logarithm $N$, which is 0.2 . $\left(\frac{t}{t_{\text {ref }}}\right)^{k}$ is the correction coefficient considering the wall thickness. Under the wall thickness conditions in this paper, the coefficient is taken as 1.0. Table 10 lists the S-N curve category for the three T-type tube-plate joints. Figure 14 shows S-N curves for the three typical joints given in Table 10. As shown in Figure 14, the fatigue strength is maximum for the T-type plate joint, given in Figure 14a, followed by the T-type tube joint, as shown in Figure 14c and the fatigue strength is minimum for the T-type tube-plate joint as shown in Figure 14b.

Based on the model established in Section 3.1 stress analysis of each typical node and fatigue analysis of three nodes are carried out. Finally, the fatigue test results of the test pieces are compared and analyzed.

Table 10. Three T-type tube-plate joints correspond to the S-N curve category.

\begin{tabular}{ccc}
\hline $\begin{array}{c}\text { The Type of Connection } \\
\text { Node }\end{array}$ & S-N Curve Category & $\begin{array}{c}\text { The Thickness Factor Is } \\
\text { Corrected }\end{array}$ \\
\hline $\begin{array}{c}\text { T-type plate joint } \\
\text { T-type tube-plate joint }\end{array}$ & E & Without \\
T-type tube joint & G & Without \\
\hline
\end{tabular}




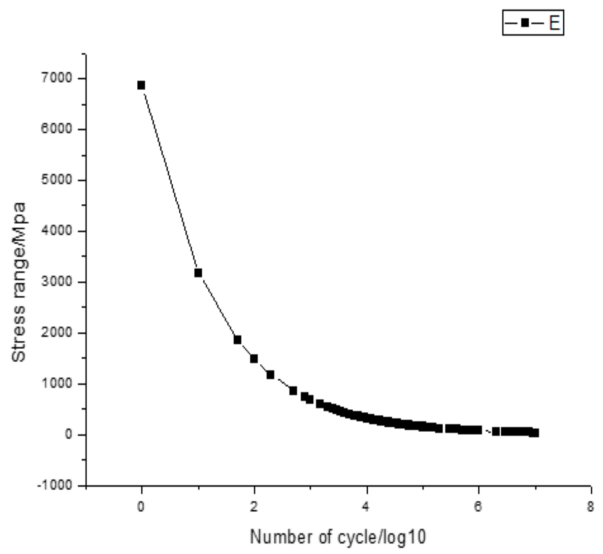

(a)

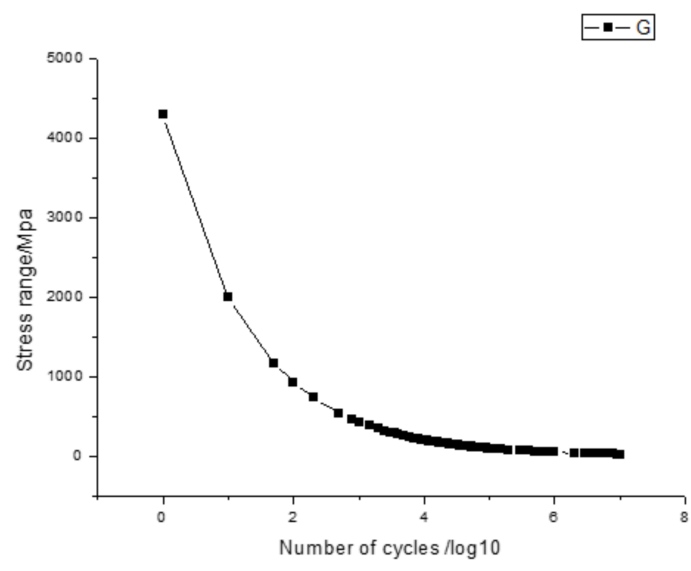

(b)

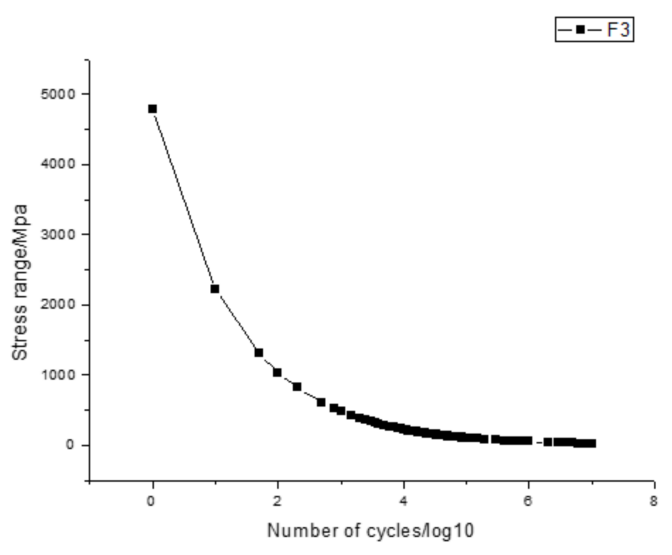

(c)

Figure 14. S-N curves for three typical joints. (a) Curve E for T-type plate joint. (b) Curve G for T-type tube-plate joint. (c) Curve F3 for T-type tube joint.

\subsection{Discussion}

3.5.1. Fatigue Damage Location

(1) T-type plate joint

It can be seen from Figure 15 that the upper weld toe area is the location of the maximum fatigue damage and has shortest fatigue life. Out of the 14 sets of fatigue tests, 9 specimens have fatigue crack damage in the upper weld toe and its vicinity, and other specimens were cracked in the lower weld toe area.

(2) T-type tube-plate joint

It can be seen from Figure 16 that the upper weld toe is the location of the largest fatigue damage and has the shortest fatigue life, and part of the lower weld toe is also the location of the largest fatigue damage. In the fatigue test, six specimens were found to have fatigue crack damage in the upper weld toe and its vicinity, and two specimens were found to have crack damage in the lower weld toe area.

(3) T-type tube joint

It can be seen from Figure 17 that the lower weld toe is the location of the largest fatigue damage and has the shortest fatigue life. Part of the upper weld toe is also the location of the largest fatigue damage. In the fatigue test, fatigue cracks were found in the 
lower weld toe and its vicinity in four specimens, and cracks were found in the upper weld toe area in three specimens.

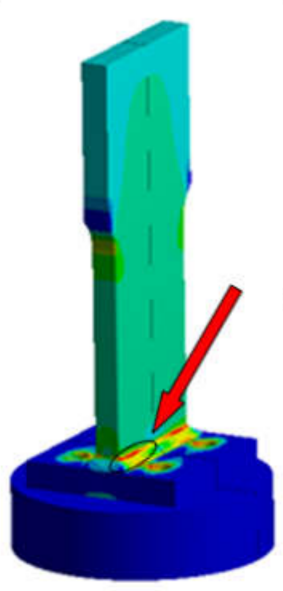

(a)

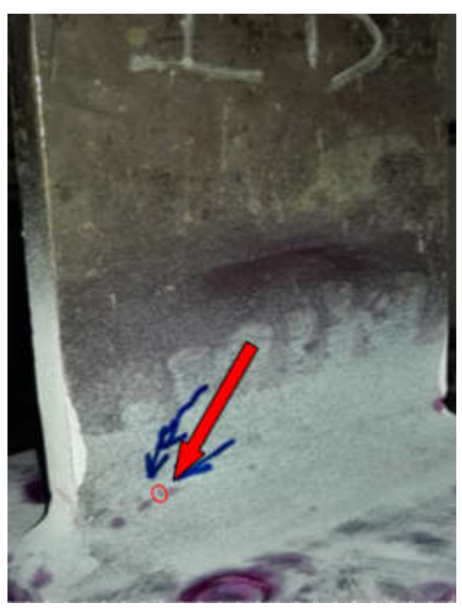

(b)

Figure 15. Comparison of fatigue damage in T-type plate joint (a) Finite element result (b) Test result.

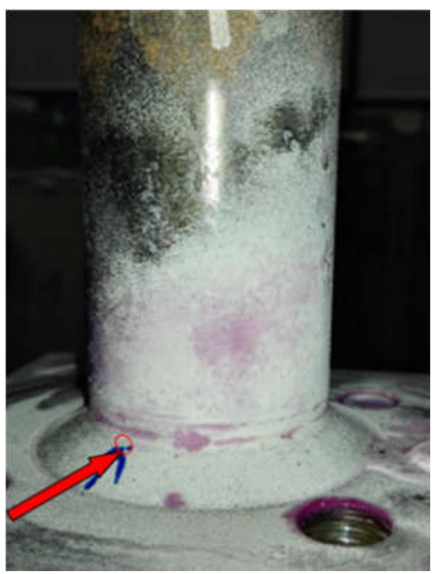

(a)

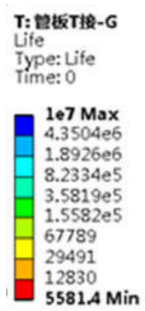

(b)

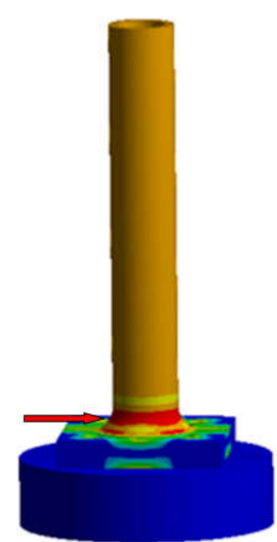

Figure 16. Comparison of fatigue damage in T-type tube-plate joint (a) Test result (b) Finite element result.

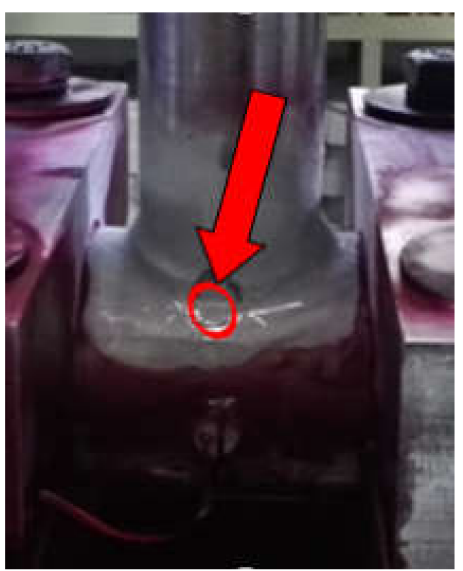

(a)

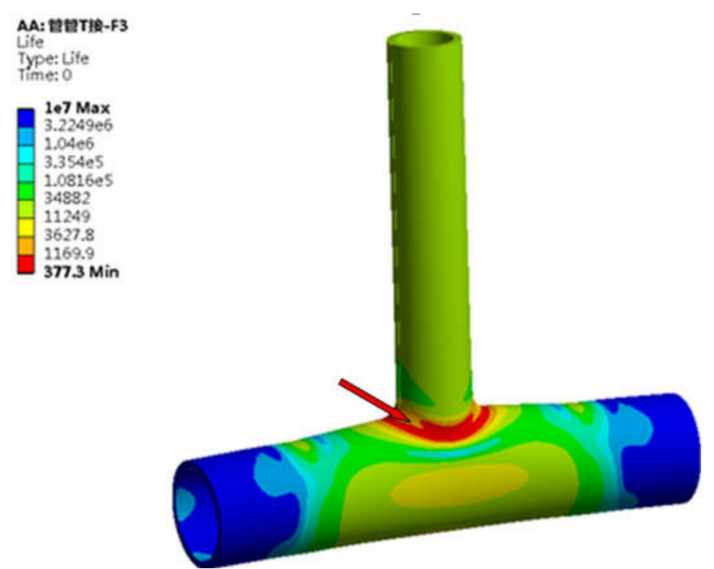

(b)

Figure 17. Comparison of fatigue damage in T-type tube joint (a) Test result (b) Finite element result. 


\subsubsection{Fatigue Life}

The fatigue test data of each type of specimen is statistically analyzed to obtain the test fatigue life, which is compared with the life obtained from the finite element analysis. The results are shown in Table 11. The finite element analysis method considers the fatigue cumulative damage analysis and the SN curve in the DNV specification; therefore, the results of the finite element analysis have large safety margins. The finite element results in Table 11 are less in magnitude than the life of the fatigue tests, which also proves that the finite element results are conservative. The large difference in the fatigue life, in Table 11, is due to the various assumptions in the modeling process. Due to its under estimation of the fatigue life, the difference is even helpful to achieve maximum safety, if the finite element modeling is used for the calculation of the fatigue life. Among them, the finite element results of T-type tube joint are small and close to those of the test, indicating that the finite element method is safe and accurate for the life prediction analysis of such joints. The results of the finite element calculation of T-type plate joint and T-type tube-plate joint are much smaller than the test results. The difference in the magnitude of the results may also be due to the hysteresis of fatigue cracks observed in the test. On the other hand, it shows that the results of finite element analysis of these three types of joints are conservative and have a relatively large safety margin.

Table 11. Comparison between the outputs of the fatigue tests and finite element analysis method.

\begin{tabular}{ccccc}
\hline Type & $\begin{array}{c}\text { Test Results } \\
\text { (Times) }\end{array}$ & $\begin{array}{c}\text { FE Results } \\
\text { (Times) }\end{array}$ & $\begin{array}{c}\text { Fatigue } \\
\text { Standard } \\
\text { Deviation }\end{array}$ & $\begin{array}{c}\text { Ratio of Finite } \\
\text { Element Life to } \\
\text { Test Life }\end{array}$ \\
\hline $\begin{array}{c}\text { T-type plate joint } \\
\text { T-type tube-plate joint }\end{array}$ & 16402 & 9113 & 18157.62 & $55.56 \%$ \\
T-type tube joint & 11856 & 5581 & 8400.58 & $47.07 \%$ \\
\hline
\end{tabular}

In summary, the results related to the damage location of the finite element analysis are in good agreement with the experimental test results. The fatigue life calculated by the finite element method is relatively small compared to the experimental test results. In the future, it is feasible and safe to predict the fatigue life by the finite element method.

As compared to the other studies in the literature, the current study is focused on an actual oil field jacket platform in Bohai Bay, China. Many of the studies in the literature are focused either on the experimental or on the numerical modeling but in the current study both the experimental and numerical modeling is performed and in the end, the results are compared. The comparison acts as a validity of the analysis performed in the current study. While most of the studies in the literature are focused on one or two types of joints, the current study is focused on the main three kinds of joints that are found in the jacket platforms, i.e., T-type plate joint, T-type tube-plate joint, and T-type tube joint. Through the fatigue test of joints, the location of fatigue damage and the development of crack damage are observed and analyzed in the current study and the fatigue life test results of joints are recorded. With the three kinds of typical joint specimens in fatigue test, the current study establishes the finite element analysis model, calculates, and analyzes the high stress and high strain regions, as well as fatigue life and fatigue damage distribution.

\section{Conclusions}

Based on the engineering data of J225-1S oil field jacket platform in Bohai Bay, three kinds of typical joints, i.e., T-type plate joint, T-type tube-plate joint, and T-type tube joint are selected for investigation in the current study. Through the fatigue test of joints, the location of fatigue damage and the development of cracks were observed and analyzed, and the fatigue life test results of joints were recorded. The outcomes of the current study are summarized below: 
(1) In the fatigue test, the fatigue crack damage can be located relatively accurately through the stained flaw detection method, combined with the digital microscope to observe the crack damage of the specimen, which can detect micro scale cracks more effectively. A crack of the size $0.463 \mathrm{~mm}$ is detected in the current study.

(2) In the early stage of fatigue crack development of joints, fatigue damage is often linear small-scale cracks (crack lengths between $0.463 \mathrm{~mm}$ and $14.640 \mathrm{~mm}$ are detected in the current study), and the propagation direction often expands along the welding direction. Early cracks when grows more are changed in a broken line shape, and slowly change after reaching a certain size, then other new cracks are also formed.

(3) The fatigue cracks of the three types of joints are the first to appear at the weld toe and its vicinity, and they spread along the welding direction. The fatigue damage location of T-type plate joint and T-type tube-plate joint is more concentrated in the upper weld toe area, and the fatigue damage location of the T-type tube joint is closer to the lower weld toe area. In engineering practice, the above-mentioned fatigue damage areas should be taken into consideration.

(4) Through finite element analysis, the high stress and strain areas of the three types of typical joints are determined. The dangerous areas appear in the weld area of the joint connection. After comparing the sensitive areas of the above joints. The test results are basically consistent, which proves the reliability of the finite element method in analyzing the fatigue damage location.

(5) The finite element calculation results and the test results are compared and analyzed. The results of the T-type tube joint are closer, and the results of T-type plate joint and T-type tube-plate joint are relatively small and still have a relatively large safety margin, which proves that the use of finite element analysis to predict fatigue life will provide large safety margin and thus it is more safe to predict the fatigue life of the joints by finite element method in engineering applications.

Author Contributions: Conceptualization, L.A., S.K., S.B., W.D., and Y.B.; methodology, L.A., S.K., S.B., N.I., W.D., and Y.B.; software, L.A., S.K., S.B., N.I., W.D., and Y.B.; validation, L.A., S.K., S.B., and Y.B.; formal analysis, L.A., S.K., S.B., N.I., W.D., and Y.B.; investigation, L.A., S.K., S.B., N.I., W.D., and Y.B.; resources, L.A., S.K., S.B., N.I., W.D., and Y.B.; data curation, L.A., S.K., S.B., N.I., W.D., and Y.B.; writing —original draft preparation, L.A., S.K., S.B., and Y.B.; writing-review and editing, L.A., S.K., S.B., N.I., W.D., and Y.B.; visualization, L.A., S.K., S.B., N.I., W.D., and Y.B. All authors have read and agreed to the published version of the manuscript.

Funding: This research received no external funding.

Institutional Review Board Statement: Not applicable.

Informed Consent Statement: Not applicable.

Data Availability Statement: The data are available by contacting the corresponding author.

Acknowledgments: The authors appreciate and acknowledge the support provided by King Fahd University of Petroleum and Minerals (KFUPM) by providing all the essential resources to conduct this study.

Conflicts of Interest: The authors declare no conflict of interest.

\section{References}

1. Madsen, H.O.; Skjong, R.K.; Tallin, A.G. Probabilistic fatigue crack growth analysis of offshore structures, with reliability updating through inspection. Proceedings of Marine Structural Symposium, Arlington, VA, USA, 5-6 October 1987; pp. 45-55.

2. Melchers, R.E. Structural Reliability Analysis and Prediction; John Wiley: Hoboken, NJ, USA, 1999.

3. Moan, T. Reliability and risk analysis for design and operations planning of offshore structures. Proceedings of 6th ICOSSAR, Structural Safety and Reliability, Balkema, Rotterdam, The Netherlands, 9-13 August 1994; Volume I, pp. 21-43.

4. Hirdaris, S.; Bai, W.; Dessi, D.; Ergin, A.; Gu, X.; Hermundstad, O.; Huijsmans, R.; Iijima, K.; Nielsen, U.; Parunov, J.; et al. Loads for use in the design of ships and offshore structures. Ocean. Eng. 2014, 78, 131-174. [CrossRef]

5. Pinheiro, B.D.C.; Pasqualino, I.P. Fatigue analysis of damaged steel pipelines under cyclic internal pressure. Int. J. Fatigue 2009, 31, 962-973. [CrossRef] 
6. Song, X.; Wang, S. A novel spectral moments equivalence based lumping block method for efficient estimation of offshore structural fatigue damage. Int. J. Fatigue 2019, 118, 162-175. [CrossRef]

7. Wisch, D.J. Fixed steel offshore structure design-past, present \& future. In Proceedings of the offshore technology conference, Houston, TX, USA, 4-7 May 1998; pp. 317-323.

8. Waegter, J.; Vissing-Jorgensen, C.; Thesbjerg, L.; Krenk, S. Pushover analysis of framed offshore structures. In Proceedings of the 17th international conference on offshore mechanics and arctic engineering, Lisbon, Portugal, 5-9 July 1998; pp. 1-6.

9. Rodrigues, P.F.N.; Jacob, B.P. Collapse analysis of steel jacket structures for offshore oil exploitation. J. Constr. Steel Res. 2005, 61, 1147-1171. [CrossRef]

10. Lee, M.M.K.; Llewelyn-Parry, A. Strength prediction for ring-stiffened DT-joints in offshore jacket structures. Eng. Struct. 2005, 27, 421-430. [CrossRef]

11. Dong, W.; Moan, T.; Gao, Z. Fatigue reliability analysis of the jacket support structure for offshore wind turbine considering the effect of corrosion and inspection. Reliab. Eng. Syst. Saf. 2012, 106, 11-27. [CrossRef]

12. Paik, J.K.; Thayamballi, A.K. Ultimate Strength of Ageing Ships. Proceedings of the Institution of Mechanical Engineers, Part M: Journal of Engineering for the Maritime Environment; Sage Publications: London, UK, 2002; pp. 57-77.

13. Akpan, U.O.; Koko, T.S.; Ayyub, B.; Dunbar, T.E. Risk assessment of ageing ship hull structures in the presence of corrosion and fatigue. Mar. Struct. 2002, 15, 211-231. [CrossRef]

14. Soares, C.G.; Garbatov, Y. Reliability of maintained ship hull girders subjected to corrosion and fatigue. Struct. Saf. 1998, 20, 201-219. [CrossRef]

15. Paik, J.; Wang, G.; Thayamballi, K.; Lee, J.; Park, Y. Time-dependent risk assessment of aging ships accounting for general/pit corrosion, fatigue cracking and local denting damage. Trans. Soc. Nav. Architects Mar. Eng. 2003, 111, $159-197$.

16. Paik, J.K.; Lee, J.M.; Ko, M.J. Ultimate shear strength of plate elements with pit corrosion wastage. Thin-Wall Struct. 2004, 42, 1161-1176. [CrossRef]

17. Paik, J.K.; Kumar, Y.S.; Lee, J.M. Ultimate strength of cracked plate elements under axial compression or tension. Thin-Wall Struct. 2005, 43, 237-272. [CrossRef]

18. Saad-Eldeen, S.; Garbatov, Y.; Soares, C.G. Experimental assessment of the ultimate strength of a box girder subjected to severe corrosion. Mar. Struct. 2011, 24, 338-357.

19. Saad-Eldeen, S.; Garbatov, Y.; Soares, C.G. Ultimate strength assessment of corroded box girders. Ocean Eng. 2013, 58, 35-47. [CrossRef]

20. Correia, J.A.; Ferradosa, T.; Castro, J.M.; Fantuzzi, N.; De Jesus, A.M. Editorial: Renewable Energy and Oceanic Structures: Part I. In Proceedings of the Institution of Civil Engineers-Maritime Engineering; Thomas Telford Ltd.: London, UK, 2019; Volume 172, pp. 1-2. [CrossRef]

21. Correia, J.A.; Ferradosa, T.; Castro, J.M.; Pavlou, D.G.; De Jesus, A.M. Editorial: Renewable Energy and Oceanic Structures: Part II. In Proceedings of the Proceedings of the Institution of Civil Engineers-Maritime Engineering; Thomas Telford Ltd.: London, UK, 2019; Volume 172, pp. 71-72.

22. Rebelo, C.; Correia, J.; Baniotopoulos, C.; De Jesus, A. Wind energy technology (WINERCOST). Wind. Eng. 2018, $42,267$. [CrossRef]

23. Jimenez-Martinez, M. Fatigue of offshore structures: A review of statistical fatigue damage assessment for stochastic loadings. Int. J. Fatigue 2020, 132, 105327. [CrossRef]

24. Moghaddam, B.T.; Hamedany, A.M.; Mehmanparast, A.; Brennan, F.; Nikbin, K.; Davies, C.M. Numerical analysis of pitting corrosion fatigue in floating offshore wind turbine foundations. Procedia Struct. Integr. 2019, 17, 64-71. [CrossRef]

25. Toft, H.S.; Svenningsen, L.; Sørensen, J.D.; Moser, W.; Thøgersen, M.L. Uncertainty in wind climate parameters and their influence on wind turbine fatigue loads. Renew. Energy 2016, 90, 352-361. [CrossRef]

26. Velarde, J.; Kramhøft, C.; Sørensen, J.D. Global sensitivity analysis of offshore wind turbine foundation fatigue loads. Renew. Energy 2019, 140, 177-189. [CrossRef]

27. Zhu, S.-P.; Liao, D.; Liu, Q.; Correia, J.A.; De Jesus, A.M. Nonlinear fatigue damage accumulation: Isodamage curve-based model and life prediction aspects. Int. J. Fatigue 2019, 128, 105185. [CrossRef]

28. Farhan, M.; Mohammadi, M.R.S.; Correia, J.A.; Rebelo, C. Transition piece design for an onshore hybrid wind turbine with multiaxial fatigue life estimation. Wind. Eng. 2018, 42, 286-303. [CrossRef]

29. Shabakhty, N.; Khansari, A. Fatigue Analysis of a Jacket Structure to Linear and Weakly Nonlinear Random Waves. J. Offshore Mech. Arct. Eng. 2019, 141, 1-29. [CrossRef]

30. Meng, D.; Hu, Z.; Wu, P.; Zhu, S.-P.; Correia, J.A.F.O.; De Jesus, A.M.P. Reliability-based optimisation for offshore structures using saddlepoint approximation. Proc. Inst. Civ. Eng. Marit. Eng. 2020, 173, 33-42. [CrossRef]

31. Zhang, M.; Wu, Q.; Wu, Y.; Du, J.; Xu, Y.; Xu, X. Fatigue damage analysis for offshore wind turbine considering coupled loads effects. In Proceedings of the 28th International Ocean and Polar Engineering Conference., Sapporo, Japan, 10-15 June 2018.

32. Fan, T.Y.; Huang, C.C.; Chu, T.L. Fatigue analysis for jacket type support structure of offshore wind turbine under local environmental conditions in Taiwan. In Proceedings of the 27th International Ocean and Polar Engineering Conference, San Francisco, CA, USA, 25-30 June 2017.

33. Yeter, B.; Garbatov, Y.; Soares, C.G. Fatigue damage assessment of fixed offshore wind turbine tripod support structures. Eng. Struct. 2015, 101, 518-528. [CrossRef] 
34. Mendes, P.; Correia, J.A.F.O.; Mourão, A.; Pereira, R.; Fantuzzi, N.; De Jesus, A.; Calçada, R. Fatigue Assessments of a Jacket-Type Offshore Structure Based on Static and Dynamic Analyses. Pract. Period. Struct. Des. Constr. 2021, 26, 04020054. [CrossRef]

35. Abd Alhusein, T.A.; Kadim, J.A. Fatigue Analysis of fixed jacket platform using FEM. Inter. J. Scie. Eng. Res. 2020, 11, 2229-5518.

36. Lin, T.-Y.; Zhao, Y.-Q.; Huang, H.-H. Representative Environmental Condition for Fatigue Analysis of Offshore Jacket Substructure. Energies 2020, 13, 5494. [CrossRef]

37. Sam, M.-T. Offshore Heavy Lift Rigging Analysis Using Spreadsheet. Pract. Period. Struct. Des. Constr. 2009, 14, 63-69. [CrossRef]

38. Dawood, N.; Marzouk, H. Design Guidelines for the Cracking Control of Thick High-Strength Concrete Members. Pract. Period. Struct. Des. Constr. 2013, 18, 122-130. [CrossRef]

39. Reddy, D.V.; Bolivar, J.C.; Sobhan, K. Durability-Based Ranking of Typical Structural Repairs for Corrosion-Damaged Marine Piles. Pract. Period. Struct. Des. Constr. 2013, 18, 225-237. [CrossRef]

40. Tang, P.; Bittner, R.B. Use of Value Engineering to Develop Creative Design Solutions for Marine Construction Projects. Pract. Period. Struct. Des. Constr. 2014, 19, 129-136. [CrossRef]

41. Gaidai, O.; Naess, A. Nonlinear Effects on Fatigue Analysis for Fixed Offshore Structures. J. Offshore Mech. Arct. Eng. 2008, 130, 031009. [CrossRef]

42. Fan, T.-Y.; Lin, C.-Y.; Huang, C.-C.; Chu, T.-L. Time-Domain Fatigue Analysis of Multi-planar Tubular Joints for a Jacket-Type Substructure of Offshore Wind Turbines. Int. J. Offshore Polar Eng. 2020, 30, 112-119. [CrossRef]

43. Liao, D.; Zhu, S.; Correia, J.A.; De Jesus, A.M.; Berto, F. Recent advances on notch effects in metal fatigue: A review. Fatigue Fract. Eng. Mater. Struct. 2020, 43, 637-659. [CrossRef]

44. Ahmadi, H.; Lotfollahi-Yaghin, M.A. Effect of SCFs on S-N based fatigue reliability of multi-planar tubular DKT-joints of offshore jacket-type structures. Ships Offshore Struct. 2013, 8, 55-72. [CrossRef]

45. Ahmadi, H.; Lotfollahi-Yaghin, M.A.; Aminfar, M.H. The development of fatigue design formulas for the outer brace SCFs in offshore three-planar tubular KT-joints. Thin-Walled Struct. 2012, 58, 67-78. [CrossRef]

46. Barbosa, J.F.; Correia, J.A.; Júnior, R.F.; Zhu, S.-P.; De Jesus, A.M. Probabilistic S-N fields based on statistical distributions applied to metallic and composite materials: State of the art. Adv. Mech. Eng. 2019, 11, 168781401987039. [CrossRef]

47. Correia, J.A.F.O.; Correia, M.; Holm, M.; Ekeborg, J.; Lesiuk, G.; Castro, J.M.; De Jesus, A.M.P.; Calçada, R. Evaluation of Fatigue Design Curves for a Double-Side Welded Connection Used in Offshore Applications. Mater. Fabr. 2018, 6A. [CrossRef]

48. Dong, P.; Hong, J.K. Fatigue of Tubular Joints: Hot Spot Stress Method Revisited. J. Offshore Mech. Arct. Eng. 2012, 134, 031602. [CrossRef]

49. Khalili, H.; Oterkus, S.; Barltrop, N.; Bharadwaj, U. Updating the Distributions of Uncertain Parameters Involved in Fatigue Analysis. J. Mar. Sci. Eng. 2020, 8, 778. [CrossRef]

50. Chryssanthopoulos, M.; Righiniotis, T. Fatigue reliability of welded steel structures. J. Constr. Steel Res. 2006, 62, 1199-1209. [CrossRef]

51. Wirsching, P.H.; Chen, Y.-N. Considerations of probability-based fatigue design for marine structures. Mar. Struct. 1988, 1, 23-45. [CrossRef]

52. Zhao, Z.; Haldar, A.; Breen, F.L. Fatigue?Reliability Updating through Inspections of Steel Bridges. J. Struct. Eng. 1994, 120, 1624-1642. [CrossRef]

53. Soares, C.G.; Garbatov, Y. Fatigue reliability of the ship hull girder accounting for inspection and repair. Reliab. Eng. Syst. Saf. 1996, 51, 341-351. [CrossRef]

54. Rajasankar, J.; Iyer, N.R.; Rao, T.A. Structural integrity assessment of offshore tubular joints based on reliability analysis. Int. J. Fatigue 2003, 25, 609-619. [CrossRef]

55. Na, W.S.; Baek, J. A Review of the Piezoelectric Electromechanical Impedance Based Structural Health Monitoring Technique for Engineering Structures. Sensors 2018, 18, 1307. [CrossRef]

56. Liang, C.; Sun, F.P.; Rogers, C.A. Coupled Electro-Mechanical Analysis of Adaptive Material Systems-Determination of the Actuator Power Consumption and System Energy Transfer. J. Intell. Mater. Syst. Struct. 1994, 5, 12-20. [CrossRef]

57. Grabulov, V.; Blačić, I.; Radović, A.; Sedmak, S. Tough ness and ductility of high strength steels welded joints. Struct. Integrity Life 2008, 8, 181-190.

58. Tawengi, A.S.; Sedmak, A.; Grabulov, V. Cold weld cracking susceptibility of high strength low alloyed HSLA steel Nionikral 70. Metalurgija 2014, 53, 624-626.

59. Qiang, X.; Bijlaard, F.S.; Kolstein, H. Elevated-temperature mechanical properties of high strength structural steel S460N: Experimental study and recommendations for fire-resistance design. Fire Saf. J. 2013, 55, 15-21. [CrossRef]

60. Topaç, M.; Günal, H.; Kuralay, N. Fatigue failure prediction of a rear axle housing prototype by using finite element analysis. Eng. Fail. Anal. 2009, 16, 1474-1482. [CrossRef]

61. Omajane, J.; Martikainen, J.; Kah, P. Weldability of thermo-mechanically rolled steels used in oil and gas offshore structures. Int. J. Eng. Sci. 2014, 3, 62-69.

62. Skowrońska, B.; Szulc, J.; Chmielewski, T.; Sałaciński, T.; Świercz, R. Properties and microstructure of hybride Plasma+MAG welded joints of thermomechanically treated S700MC steel. In Proceedings of the 27th Anniversary International Conference on Metallurgy and Materials (METAL), Brno, Czech Republic, 23-25 May 2018.

63. Pańcikiewicz, K.; Tuz, L.; Żurek, Z.; Rakoczy, Ł. Optimization of Filler Metals Consumption in the Production of Welded Steel Structures. Adv. Mater. Sci. 2016, 16, 27-34. [CrossRef] 
64. Sajek, A.; Nowacki, J. Comparative evaluation of various experimental and numerical simulation methods for determination of $\mathrm{t}$ 8/5 cooling times in HPAW process weldments. Arch. Civ. Mech. Eng. 2018, 18, 583-591.

65. Górka, J. Assessment of Steel Subjected to the Thermomechanical Control Process with Respect to Weldability. Metals 2018, 8, 169. [CrossRef]

66. Łabanowski, J.; Prokop-Strzelczyńska, K.; Rogalski, G.; Fydrych, D. The Effect of Wet Underwater Welding on Cold Cracking Susceptibility of Duplex Stainless Steel. Adv. Mater. Sci. 2016, 16, 68-77. [CrossRef]

67. Li, H.; Liu, D.; Guo, N.; Chen, H.; Du, Y.; Feng, J. The effect of alumino-thermic addition on underwater wet welding process stability. J. Mater. Process. Technol. 2017, 245, 149-156. [CrossRef]

68. Purnama, D.; Winarto, W.; Susilo, F.H. Human-dedicated sustainable product and process design: Materials, resources, and energy. In Proceedings of the 4th International Conference on Engineering, Technology, and Industrial Application (ICETIA), Surakarta, Indonesia, 13 December 2017; Volume 1977, p. 030015. [CrossRef]

69. Tomków, J.; Fydrych, D.; Rogalski, G.; Łabanowski, J. Temper Bead Welding of S460N Steel in Wet Welding Conditions. Adv. Mater. Sci. 2018, 18, 5-14. [CrossRef]

70. Tomków, J.; Fydrych, D.; Rogalski, G. Dissimilar underwater wet welding of HSLA steels. Int. J. Adv. Manuf. Technol. 2020, 109, 717-725. [CrossRef]

71. Yin, Y.; Yang, X.; Cui, L.; Cao, J.; Xu, W. Microstructure and mechanical properties of underwater friction taper plug weld on X65 steel with carbon and stainless steel plugs. Sci. Technol. Weld. Join. 2016, 21, 259-266. [CrossRef]

72. Heirani, F.; Abbasi, A.; Ardestani, M. Effects of processing parameters on microstructure and mechanical behaviors of underwater friction stir welding of Al5083 alloy. J. Manuf. Process. 2017, 25, 77-84. [CrossRef]

73. Rogalski, G.; Fydrych, D.; Łabanowski, J. Underwater Wet Repair Welding of API 5L X65M Pipeline Steel. Pol. Marit. Res. 2017, 24, 188-194. [CrossRef]

74. Chen, H.; Guo, N.; Shi, X.; Du, Y.; Feng, J.; Wang, G. Effect of water flow on the arc stability and metal transfer in underwater flux-cored wet welding. J. Manuf. Process. 2018, 31, 103-115. [CrossRef]

75. Shi, Y.; Lin, S.; Hu, Y.; Yi, Y.; Li, Z. Porosity and Microstructure of Underwater Wet FCAW of Duplex Stainless Steel. Met. Microstruct. Anal. 2017, 6, 383-389. [CrossRef]

76. Fydrych, D.; Łabanowski, J.; Tomków, J.; Rogalski, G. Cold Cracking Of Underwater Wet Welded S355G10+N High Strength Steel. Adv. Mater. Sci. 2015, 15, 48-56. [CrossRef]

77. Maksimov, S. Underwater arc welding of higher strength low-alloy steels. Weld. Int. 2010, 24, 449-454. [CrossRef]

78. Hart, P.H.M. Weld metal hydrogen cracking in pipeline Girth welds. In Proceedings of the 1st International Conference, Wollongong, NSW, Australia, 1-2 March 1999.

79. Wilhelmsen Ships Service. Defects - Hydrogen Cracks in Steels - Prevention and Best Practice. Available online: https://www. twi-global.com/technical-knowledge/job-knowledge/defects-hydrogen-cracks-in-steels-prevention-and-best-practice-046 (accessed on 4 May 2021).

80. Hydrogen Embrittlement an Over View from a Mecha Nical Fastenings Aspect, FERA 17 Nothwick Crescent Solihull West Midlands B91 3TU. 2000. Available online: https:/ / www.diva-portal.org/smash/get/diva2:1024622/FULLTEXT01.pdf (accessed on 4 May 2021).

81. Urbikain, G.; Perez, J.M.; López de Lacalle, L.N.; Andueza, A. Combination of friction drilling and form tapping processes on dissimilar materials for making nutless joints. Proc. Inst. Mech. Eng. Part B J. Eng. Manuf. 2018, 232, 1007-1020. [CrossRef]

82. Dixit, U.; Joshi, S.; Davim, J. Incorporation of material behavior in modeling of metal forming and machining processes: A review. Mater. Des. 2011, 32, 3655-3670. [CrossRef]

83. Silva, C.A.; Rosa, P.A.R.; Martins, P.A.F. Innovative testing machines and methodologies for the mechanical characterization of materials. Exp. Tech. 2016, 40, 569-581. [CrossRef]

84. Krahmer, D.M.; Polvorosa, R.; De Lacalle, L.N.L.; Alonso-Pinillos, U.; Abate, G.; Riu, F. Alternatives for Specimen Manufacturing in Tensile Testing of Steel Plates. Exp. Tech. 2016, 40, 1555-1565. [CrossRef]

85. Khan, S.; Al-Shuhail, A.A.; Khulief, Y.A. Numerical modeling of the geomechanical behavior of Ghawar Arab-D carbonate petroleum reservoir undergoing $\mathrm{CO}_{2}$ injection. Environ. Earth Sci. 2016, 75, 1-15. [CrossRef]

86. Israf, U.D.; Usman, M.; Khan, S.; Aasif, H.; Alotaibi, M.A.; Alharthi, A.I.; Centi, G. Prospects for a green methanol thermo-catalytic process from $\mathrm{CO} 2$ by using MOFs based materials: A mini-review. J. CO2 Util. 2020. [CrossRef]

87. Khan, S.; Khulief, Y.A.; Al-Shuhail, A.A. The effect of injection well arrangement on CO2 injection into carbonate petroleum reservoir. Int. J. Glob. Warm. 2018, 14. [CrossRef]

88. Garba, M.D.; Muhammad, U.; Khan, S.; Farrukh, K.; Ahmad, S.; Muhamad, G.; Akram, F.E.; Muhammad, H. CO2 towards fuels: A review of catalytic conversion of carbon dioxide to hydrocarbons. J. Environ. Chem. Eng. 2020. [CrossRef]

89. Khan, S.; Khulief, Y.A.; Al-Shuhail, A.A. Numerical modeling of the geomechanical behavior of Biyadh Reservoir undergoing CO2 injection. Int. J. Geomech. 2017, 17, 1-12. [CrossRef]

90. Khan, S.; Khulief, Y.A.; Al-Shuhail, A.A. Alleviation of pore pressure buildup and ground uplift during carbon dioxide injection into Ghawar Arab-D carbonate naturally fractured reservoir. Environ. Earth Sci. 2018, 77. [CrossRef]

91. Hamad, H.; Bai, Y.; Ali, L. A risk-based inspection planning methodology for integrity management of subsea oil and gas pipelines. Ships Offshore Struct. 2020. [CrossRef] 
92. Ali, L.; Bai, Y.; Jin, S. Risk Assessment and reliability analysis of subsea production Systems. In Proceedings of the ASME 2020 39th International Conference on Ocean, Offshore and Arctic Engineering, Virtual Conference, 3-7 August 2020. [CrossRef]

93. Ali, L.; Bai, Y.; Xu, Y. A methodology to derive design metocean internal wave current for submarine structures. Ships Offshore Struct. 2020. [CrossRef]

94. Ali, L.; Nawaz, A.; Bai, Y. Numerical simulations of GFRP-Reinforced columns having polypropylene and polyvinyl alcohol fibers. Hindawi Complex. 2020. [CrossRef]

95. Jimenez, M. DURABILITY TESTS: Statistical analysIs for variable amplitude loads. Trans. Can. Soc. Mech. Eng. 2017, 41, 910-921. [CrossRef]

96. ISO 12107, Metallic materials—Fatigue Testing-Statistical Planning and Analysis of Data. Available online: https://www.iso. org/standard/50242.html (accessed on 4 May 2021).

97. Department of Energy, Background to New Fatigue Design UKOSRP II/PSC/P85-2T, from 16/9/84 to 5/1/85. guidance for steel welded joints in offshore structures, Report of the Department of Energy Guidance Notes Revision Draft Panel. HMSO, 1984. Available online: https:/ / www.amazon.com/Background-fatigue-guidance-offshore-structures/dp/0114114560 (accessed on 4 May 2021).

98. Guidance on Design, Construction and Certification, 4th ed.; HMSO, Department of Energy: London, UK, 1990; (including amendment No. 3 published in February 1995).

99. Wylde, J.G. Fatigue Tests on Welded Tubular Joints in Air and Sea Water, TWI Research Report 251/1984, 1984 (Confidential to Industrial Members of TWI). Available online: https:/ /www.twi-global.com/what-we-do/research-and-technology/ research-reports/industrial-member-reports / fatigue-tests-on-welded-tubular-joints-in-air-and-sea-water-251-1984 (accessed on 4 May 2021).

100. Wylde, J.G. Seawater Corrosion Fatigue Tests on Steel Tubular Joints, Internal TWI Report 7921.01/87/589.2. 1988. Available online: https:/ / www.twi-global.com/technical-knowledge/published-papers/review-and-assessment-of-fatigue-data-foroffshore-structural-components-containing-through-thickness-cracks-june-2008 (accessed on 4 May 2021).

101. Eide, O.I.; Berge, S. Fatigue capacity of stiffened tubular joints. In Proceedings of the 9th International Conference on Offshore Mechanics and Arctic Engineering, Houston, TX, USA, 18-23 February 1990; Volume 3, p. 209.

102. Macdonald, A.; Brown, C.M.; Thomson, J.F.; Kerr, J. Strain Distribution Measurement and Fatigue Tests on Welded Tubular Joints, Report No. B12 in United Kingdom Offshore Steels Research Project-Phase I Research Contract Reports, Department of Energy, OTI 89 540,1988. Available online: https://www.twi-global.com/technical-knowledge/published-papers/ straindistributionmeasurementandfatiguetestsonweldedtubularjoints (accessed on 4 May 2021).

103. Fatigue Analysis of Unbonded Flexible Pipe. In Y.B Qiang Bai Flexible Pipes (P.225) Hoboken, NJ, USA Martian Srivencer. Available online: https:// onepetro.org/OTCONF/proceedings-abstract/07OTC/All-07OTC/OTC-18905-MS/37377 (accessed on 4 May 2021). 